\title{
Impact of ocean acidification on Arctic phytoplankton blooms and dimethyl sulfide concentration under simulated ice-free and under-ice conditions
}

\author{
Rachel Hussherr $^{1}$, Maurice Levasseur ${ }^{1}$, Martine Lizotte $^{1}$, Jean-Éric Tremblay ${ }^{1}$, Jacoba Mol $^{2}$, Helmuth Thomas $^{2}$, \\ Michel Gosselin $^{3}$, Michel Starr ${ }^{4}$, Lisa A. Miller ${ }^{5}$, Tereza Jarniková ${ }^{6}$, Nina Schuback ${ }^{6}$, and Alfonso Mucci ${ }^{7}$ \\ ${ }^{1}$ Québec-Océan and Takuvik joint UL-CNRS laboratory, Département de biologie, Université Laval, \\ Québec, Québec G1V 0A6, Canada \\ ${ }^{2}$ Department of Oceanography, Dalhousie University, Halifax, Nova Scotia B3H 4R2, Canada \\ ${ }^{3}$ Institut des sciences de la mer de Rimouski, Université du Québec à Rimouski, Rimouski, Québec G5L 3A1, Canada \\ ${ }^{4}$ Maurice Lamontagne Institute, Fisheries and Oceans Canada, Mont-Joli, Québec G5H 3Z4, Canada \\ ${ }^{5}$ Institute of Ocean Sciences, Fisheries and Oceans Canada, Sidney, British Columbia V8L 4B2, Canada \\ ${ }^{6}$ Department of Earth, Ocean and Atmospheric Sciences, University of British Columbia, Vancouver, \\ British Columbia V6T 1Z4, Canada \\ ${ }^{7}$ GEOTOP and Department of Earth and Planetary Sciences, McGill University, Montréal, Québec H3A 0E8, Canada
}

Correspondence to: Rachel Hussherr (rachel.hussherr@gmail.com)

Received: 18 November 2016 - Discussion started: 6 December 2016

Revised: 23 March 2017 - Accepted: 6 April 2017 - Published: 12 May 2017

\begin{abstract}
In an experimental assessment of the potential impact of Arctic Ocean acidification on seasonal phytoplankton blooms and associated dimethyl sulfide (DMS) dynamics, we incubated water from Baffin Bay under conditions representing an acidified Arctic Ocean. Using two light regimes simulating under-ice or subsurface chlorophyll maxima (low light; low PAR and no UVB) and ice-free (high light; high PAR + UVA + UVB) conditions, water collected at $38 \mathrm{~m}$ was exposed over 9 days to 6 levels of decreasing $\mathrm{pH}$ from 8.1 to 7.2. A phytoplankton bloom dominated by the centric diatoms Chaetoceros spp. reaching up to $7.5 \mu \mathrm{g}$ chlorophyll $a \mathrm{~L}^{-1}$ took place in all experimental bags. Total dimethylsulfoniopropionate $\left(\mathrm{DMSP}_{\mathrm{T}}\right)$ and DMS concentrations reached 155 and $19 \mathrm{nmol} \mathrm{L}^{-1}$, respectively. The sharp increase in $\mathrm{DMSP}_{\mathrm{T}}$ and DMS concentrations coincided with the exhaustion of $\mathrm{NO}_{3}^{-}$in most microcosms, suggesting that nutrient stress stimulated DMS(P) synthesis by the diatom community. Under both light regimes, chlorophyll $a$ and DMS concentrations decreased linearly with increasing proton concentration at all $\mathrm{pH}$ levels tested. Concentrations of $\mathrm{DMSP}_{\mathrm{T}}$ also decreased but only under high light and over a smaller $\mathrm{pH}$ range (from 8.1 to 7.6). In contrast to nanophytoplankton $(2-20 \mu \mathrm{m})$, pico-phytoplankton $(\leq 2 \mu \mathrm{m})$ was
\end{abstract}

stimulated by the decreasing $\mathrm{pH}$. We furthermore observed no significant difference between the two light regimes tested in term of chlorophyll $a$, phytoplankton abundance and taxonomy, and DMSP and DMS net concentrations. These results show that ocean acidification could significantly decrease the algal biomass and inhibit DMS production during the seasonal phytoplankton bloom in the Arctic, with possible consequences for the regional climate.

\section{Introduction}

As a result of anthropogenic emissions of carbon dioxide $\left(\mathrm{CO}_{2}\right)$ to the atmosphere, important transformations are observed in the global ocean, including a rise in water temperature, a decrease in ocean $\mathrm{pH}$, modifications of water circulation patterns and nutrient distributions, and a loss of sea ice in the Arctic (ACIA, 2005; Fabry et al., 2009; Macdonald et al., 2015). Due to various feedback processes, the atmospheric temperature in the Arctic region above $64^{\circ} \mathrm{N}$ has warmed by $1.9^{\circ} \mathrm{C}$ between 1981 and 2012, a rate 3 times higher than the global average (ACIA, 2005; Ford et al., 2015). This phe- 
nomenon, known as the Arctic amplification (Cohen et al., 2014), is leading to the greatest regional transformations observed in the recent decades (ACIA, 2005). Given that the reduction in the extent and thickness of the sea-ice cover and the acidification of surface waters are two factors that can potentially affect Arctic primary productivity, it is important to consider the associated effects on the production of biogenic climate-active gases such as dimethyl sulfide (DMS).

Since the pre-industrial era, the ocean has absorbed more than one quarter of the anthropogenic $\mathrm{CO}_{2}$ emitted to the atmosphere (Feely et al., 2009, and references therein). This phenomenon alters the chemistry of seawater and results in a decrease in $\mathrm{pH}$. The dissolution of anthropogenic $\mathrm{CO}_{2}$ has already led to an estimated 0.1 unit decrease of $\mathrm{pH}$ in the global ocean surface waters (Feely et al., 2009). An additional decrease of $0.2 \mathrm{pH}$ unit is anticipated by the end of the century and as much as 0.8 is expected by 2300 , depending on future net $\mathrm{CO}_{2}$ emissions (Caldeira and Wickett, 2003; Raven et al., 2005; Doney et al., 2009; Feely et al., 2009). Owing to the lower buffer capacity and greater solubility of $\mathrm{CO}_{2}$ in cold waters and the dilution of total alkalinity (TA) by freshwater due to sea-ice melt and river run-off, a more rapid decline of $0.45 \mathrm{pH}$ unit is predicted by 2100 for Arctic waters under IPCC SRES emission scenario A2 (Steinacher et al., 2009).

During the last 2 decades, many studies have attempted to quantify the sensitivity of marine ecosystems to ocean acidification (OA). Since the dissolution of atmospheric $\mathrm{CO}_{2}$ increases its concentration in seawater, low $\mathrm{pH}$-high $p \mathrm{CO}_{2}$ environments could enhance phytoplankton growth rate by facilitating $\mathrm{CO}_{2}$ uptake and reducing the energy cost of the Carbon Concentrating Mechanism (CCM, cellular processes used by algae to overcome $\mathrm{CO}_{2}$ limitation in water) in some phytoplankton species (Gao and Campbell, 2014 and references therein). Accordingly, a decrease in $\mathrm{pH}$ has been reported to stimulate carbon fixation by phytoplankton (Doney et al., 2009; Gao and Campbell, 2014; Wu et al., 2014; Mackey et al., 2015; Thoisen et al., 2015), but negative impacts of decreasing $\mathrm{pH}$ on phytoplankton growth have also been reported and attributed to $\mathrm{pH}$-induced alterations in algal cell physiology, acid-base chemistry, trace metal availability, ion transport, protein functions, and nutrient uptake (Doney et al., 2009; Gao and Campbell, 2014; Richier et al., 2014; Mackay et al., 2015; Thoisen et al., 2015). Due to these potential antagonist effects, it is still difficult to predict how a specific bloom in a given area will respond to the projected decrease of ocean $\mathrm{pH}$.

A ubiquitous, biogenic trace gas produced in the ocean (Keller et al., 1989; Townsend and Keller, 1996; Kiene et al., 2000), DMS, accounts for $80 \%$ of the biogenic sulfur emitted from the ocean to the atmosphere (Kettle and Andreae, 2000). Once released to the atmosphere, DMS undergoes a rapid photochemical transformation into sulfate, which may result in an increase in the concentration of sulfate aerosols and cloud condensation nuclei. Emissions of DMS can thus increase cloud albedo and potentially cool the climate (Ferek et al., 1995; Quinn et al., 2002). The effect of DMS on climate is particularly important in regions of low aerosol burden, such as the summer Arctic atmosphere (Mungall et al., 2016). This gas is mostly produced by the degradation of dimethylsulfoniopropionate (DMSP), a cellular compound present in the majority of phytoplankton species where it fulfils several physiological functions, including osmoregulation (Dickson et al., 1980; Kirst, 1996; Van Bergeijk et al., 2003), cryo-protection (Kirst et al., 1991), and protection against reactive oxygen species (Sunda et al., 2002). A significant fraction of algal DMSP is released to the water column by exudation or from grazing, constituting a dissolved pool that is rapidly consumed by heterotrophic bacteria, which can cleave it into DMS (the "cleavage pathway") or metabolise it via the demethylation-demethiolation pathway (Kiene et al., 2000). Both unicellular algae and bacteria can thus convert DMSP to DMS, their relative contribution being governed by the taxonomic composition of the phytoplankton community, as well as the abundance and physiological state of the bacteria (Stefels et al., 2007). Oceanic DMS production is thus closely linked to phytoplankton bloom development, which also makes it potentially sensitive to OA.

Several studies have already highlighted the sensitivity of DMS production to decreases in seawater $\mathrm{pH}$. The majority of these experimental studies revealed a negative impact of decreasing $\mathrm{pH}$ on DMS production (Hopkins et al., 2010; Avgoustidi et al., 2012; Archer et al., 2013; Webb et al., 2016), but some have reported either no effect or a positive effect (Vogt et al., 2008; Hopkins and Archer, 2014). Several hypotheses have been proposed to explain these contrasting results. Some authors attribute the $\mathrm{pH}$-induced variation in DMS production to an alteration of the physiological properties of the phytoplankton cells or of the bacterial DMSP metabolism (Vogt et al., 2008; Hopkins et al., 2010, Avgoustidi et al., 2012; Archer et al., 2013; Hopkins and Archer, 2014; Webb et al., 2015, 2016), whereas others evoke an interaction between the DMSP producers and their grazers (Kim et al., 2010; Park et al., 2014). So far, only one study has looked at the impact of OA on DMS dynamics in the Arctic (Archer et al., 2013). The results of this mesocosm study, conducted near Svalbard, show a decrease in DMS concentrations at low $\mathrm{pH}$, suggesting that $\mathrm{OA}$ may significantly reduce DMS emissions to the atmosphere in the Arctic.

The main objective of this study was to experimentally assess the impact of decreasing $\mathrm{pH}$ on the DMS produced by an Arctic phytoplankton seasonal bloom. Furthermore, we investigated how light conditions corresponding to those experienced by a marginal ice phytoplankton bloom and an under-ice or subsurface phytoplankton bloom could modulate the effects of $\mathrm{pH}$ on phytoplankton and DMS variations. The latter was motivated by the strong contribution of subsurface phytoplankton layers to annual productivity in several sectors of the Arctic as well as the apparent increasing occurrence of under-ice blooms, attributed to the thinning of 
sea ice and the replacement of the multi-year ice by first-year ice (Martin et al., 2010; Frey et al., 2011; Palmer et al., 2014 and references therein).

\section{Methods}

\subsection{Initial water collection and experimental setting}

The incubation experiment was conducted on board of the Canadian research icebreaker CCGS Amundsen between 6 and 15 August 2015. The water was collected near the nitracline at $38 \mathrm{~m}$ depth at station BB-3 in Baffin Bay (see Fig. 1) using 12 L Niskin-type bottles deployed on a CTD rosette system. Since the cruise took place after the summer bloom in this part of the Arctic, we collected the water between the subsurface chlorophyll maximum (SCM) and the nitracline in order to have sufficient nutrient to support a bloom during our incubation. In situ temperature and salinity were respectively $-1.35^{\circ} \mathrm{C}$ and 32.67 at the sampling depth. All water manipulations were done under dim light conditions in order to protect the cells from potential light shock. After the initial collection, water was gravity-filtered through a $200 \mu \mathrm{m}$ Nitex mesh, in order to remove large grazers, and transferred to 12 gas-tight $10 \mathrm{~L}$ bags (HyClone Labtainer $\odot$, Thermo Scientific) using a Teflon tube installed between the Niskin bottle and the Luer valve of each bag. All 12 bags were placed in an incubator on the ship's foredeck, through which surface water was circulated to maintain the incubation bags close to sea surface temperature. Since our deck incubator was cooled with circulating surface water, we had no control over the temperature during the incubation (mean temperature of $4.3 \pm 1.6^{\circ} \mathrm{C}$ over the 9-day experiment). However, all bags were in the same incubator, and hence submitted to the same temperature. An insulated box (a "cooler") was used to transport the samples whenever they had to be carried between the incubator and the ship-board laboratory. Water temperature was monitored every $15 \mathrm{~min}$ during the entire experiment using a RBR TR-1060 temperature recorder. Incident photosynthetically active radiation (PAR, $400-700 \mathrm{~nm}$ ) was monitored continuously using a LI-1000 data logger combined with a LI-190SA cosine sensor (LICOR) located near the incubator. Incident UVA (SED033 detector/UVA filter/W diffuser) and UVB (SED240 detector/UVB filter/W diffuser) radiation was measured daily (day 5 to 9 only due to instrument dysfunction during the first 4 days) at around midday with an IL1700 radiometer (International Light).

\subsection{Treatments and acidification protocol}

\subsubsection{Acidification protocol}

For this experiment, the phytoplankton communities were exposed to a $\mathrm{pH}$ gradient and two light regimes. A total of 12 incubation bags were separated into 2 groups of 6 bags to produce two similar sets of $\mathrm{pH}$ gradients (con-

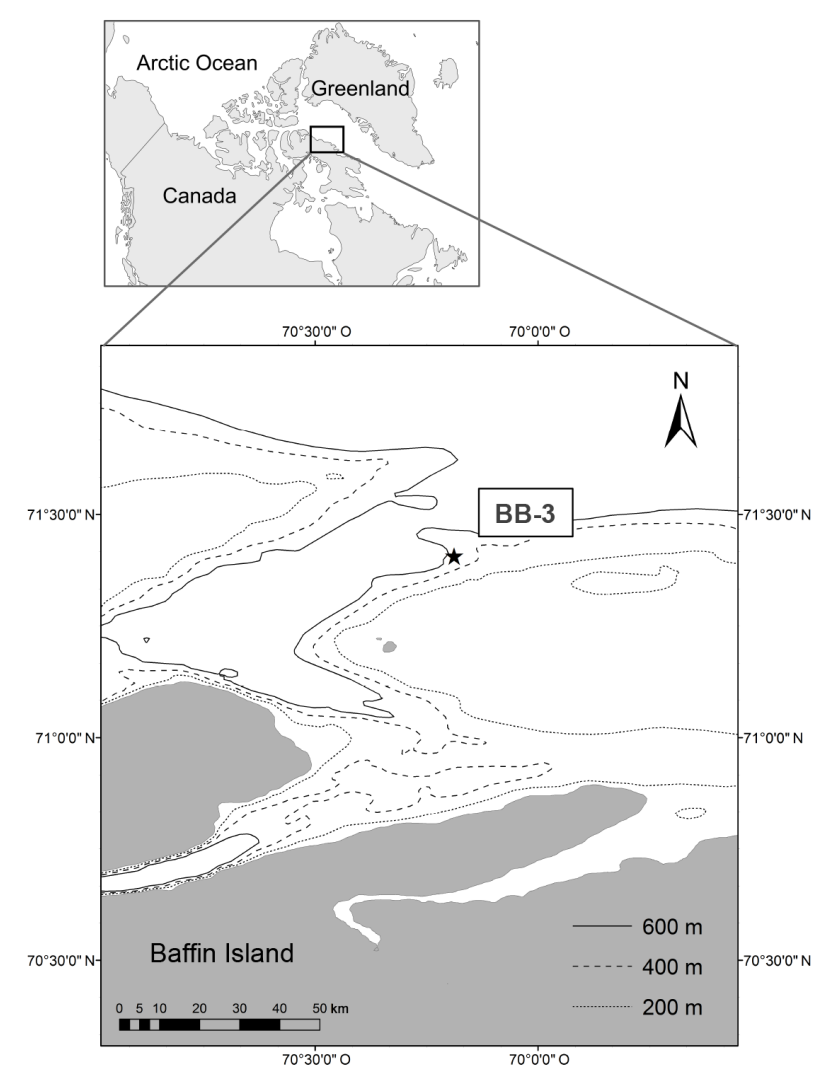

Figure 1. Map showing the location of station BB-3 $\left(71^{\circ} 24.373^{\prime} \mathrm{N}\right.$, $70^{\circ} 11.269^{\prime} \mathrm{W}$ ), where seawater was collected for the incubation experiment.

trol +5 acidified bags; Table 1). The $\mathrm{pH}$ gradient method has been successfully applied by Schulz et al. (2013) and Paul et al. (2016) and is suitable when the possibility of replication is limited (see Cottingham et al., 2005, and Havenhand et al., 2010, for more details).

After equilibrating at incubator temperature, the "noncontrol" samples were taken to the lab and acidified (at time T0, 6 August) by addition of strong acid and bicarbonate $\left(\mathrm{HCl}, 0.02 \mathrm{~N} ; \mathrm{NaHCO}_{3}, 0.3 \mathrm{~N}\right)$ following procedures described by Riebesell et al. (2010). By keeping the alkalinity constant, this procedure mimics the natural acidification process as observed in global ocean waters. The volumes needed to reach each targeted $\mathrm{pH}$ value on the total hydrogen ion scale $\left(\mathrm{mol} \mathrm{kg}^{-1}\right.$ seawater $\left.-\mathrm{SW}\right)$ were determined with the help of the MS Excel macro $\mathrm{CO}_{2} \mathrm{SYS}$ (Pierrot et al., 2006) (using the carbonic acid dissociation constants $\left(K_{1}\right.$ and $\left.K_{2}\right)$ of Lueker et al., 2000 and the bisulfate dissociation constant $\left(K_{\mathrm{HSO}_{4}}\right)$ of Dickson, 1990). The acid and bicarbonate solutions were added in appropriate proportions to each bag using a syringe connected to the Luer-lock port of the bag. After acidification, each bag was gently inverted around 10 times before being returned to the incubator. The entire process of the bags' acidification was completed within $4 \mathrm{~h}$. The incu- 
Table 1. Values of $\mathrm{pH}_{\mathrm{T}}$ (total hydrogen ion scale), the associated proton concentration $\left[\mathrm{H}^{+}\right]$, dissolved inorganic carbon (DIC), total alkalinity (TA), and $p \mathrm{CO}_{2}$ in the microcosms under low light (LL) and high light (HL) treatments on days T0, T1, T4, and T9. Values of $p \mathrm{CO} 2$ were calculated using $\mathrm{CO}_{2} \mathrm{SYS}$ software; values of proton concentrations were calculated after the $\mathrm{pH}_{\mathrm{T}}$ measurements. $1 \mathrm{~L}$ and $1 \mathrm{H}$ are the control microcosms.

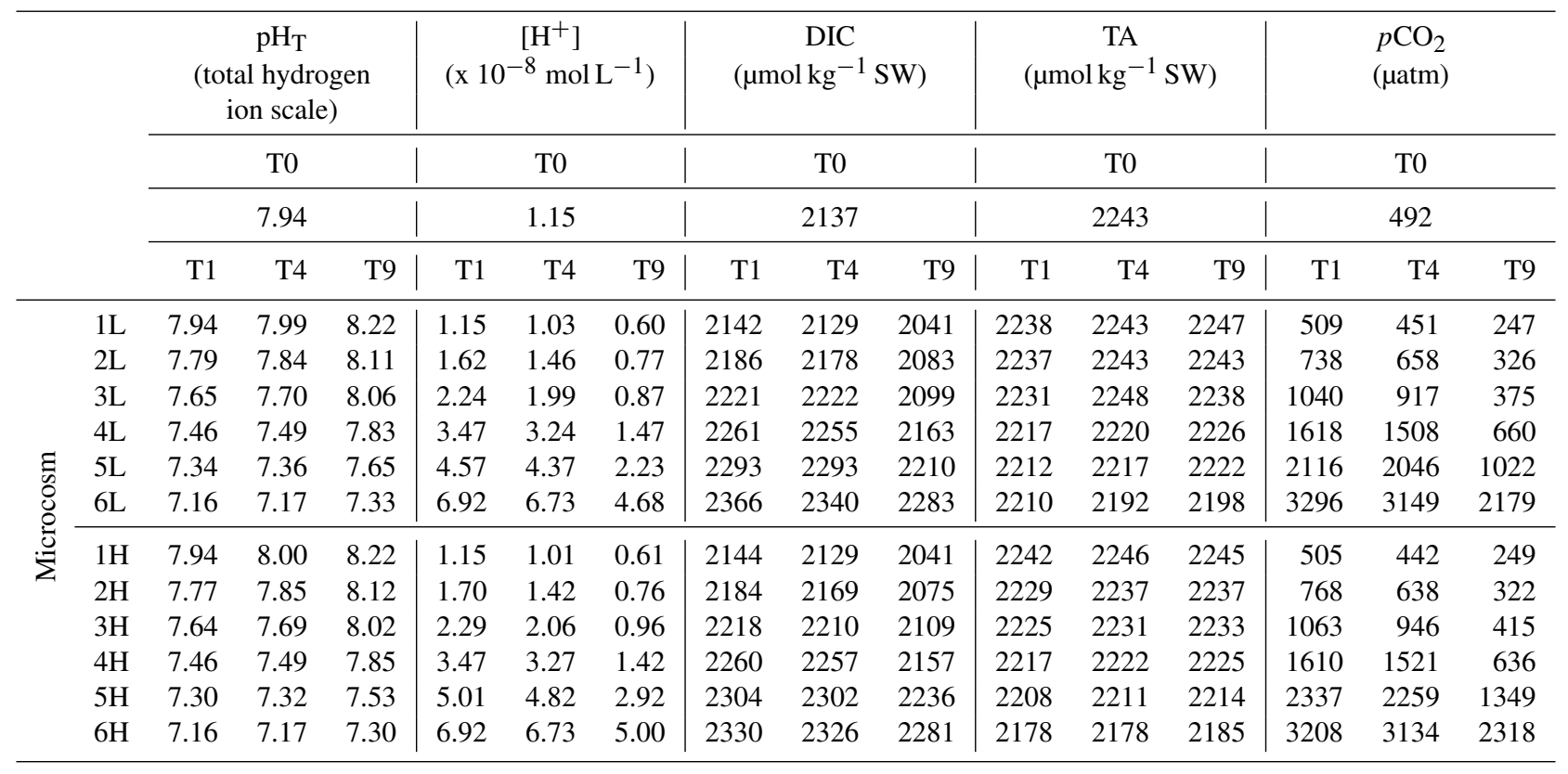

bator was then covered with a white canvas sheet until sunset and bags remained overnight in the incubator without further manipulation. After the initial acidification, the carbonate chemistry was not manipulated and the only changes in $\mathrm{pH}$ that occurred during the experiment were due to biological activity. Subsampling began the next day in the morning (T1, 7 August, around 07:00 LT).

\subsubsection{Light treatments}

Once acidified, each set of incubation bags covering the initial $\mathrm{pH}$ values between 8.1 and 7.2 was assigned to a light treatment (Tables 1 and 2): "low light" (LL, 6 bags), and "high light" (HL, 6 bags). The transmittance through the incubation bags of both LL and HL treatments was determined in the laboratory using a Perkin Elmer LAMBDA 850 Spectrophotometer. We based our experimental LL conditions (PAR, UVA, and UVB transmittance of 32.6, 20.6, and $0 \%$, respectively) on a model of the minimal light conditions required to trigger an under-ice bloom (Palmer et al., 2014) and available data from measurements of UV and PAR under ponded ice (Trodahl and Buckley, 1990; Perovich et al., 1998; Belzile et al., 2000; Frey et al., 2011; Palmer et al., 2014). As UVB is strongly attenuated by sea ice and thus likely negligible at $5 \mathrm{~m}$ depth under the ice (Frey et al., 2011; Palmer et al., 2014), those short wavelengths were eliminated. The LL treatment transmittances were achieved by covering the six LL bags with two layers of Nitex mesh $(300 \mu \mathrm{m})$ and one layer of Mylar D film $(0.13 \mathrm{~mm}$ thick;
Demers et al., 1998). The Nitex mesh attenuated the entire light spectrum equally whereas the Mylar D film specifically removed the leftover UVB radiation (Demers et al., 1998; Roux et al., 2002). The resulting transmittance measured through the incubation bags under LL treatment was similar to light conditions encountered at $5 \mathrm{~m}$ depth under the ice in early summer (Frey et al., 2011) or at subsurface chlorophyll maxima, which are widespread in the Arctic Ocean (Martin et al., 2010, 2013).

The incubation bags dedicated to the HL treatment (PAR, UVA, and UVB transmittance of 77.5, 61.5, and $32.6 \%$, respectively) were exposed to light conditions representing a typical Arctic upper mixed layer of approximately $5 \mathrm{~m}$ depth, based on the equation of Riley (1957):

$E_{z}=E_{0} \times \frac{1-e^{-K_{\mathrm{d}} \times Z}}{K_{\mathrm{d}} \times Z}$,

where $E_{z}$ ( $\mu$ mol quanta $\mathrm{m}^{-2} \mathrm{~s}^{-1}$ ) is the daily PAR averaged over the surface mixed layer, $E_{0}$ ( $\mu$ mol quanta $\mathrm{m}^{-2} \mathrm{~s}^{-1}$ ) is the daily averaged PAR at the surface, $K_{\mathrm{d}}$ is the PAR diffuse attenuation coefficient (assumed to be $0.123 \mathrm{~m}^{-1}$; unpublished data from Baffin Bay, M. Gosselin), and $Z$ (m) is the surface mixed layer depth. The attenuation of incident light for the HL treatment was only due to the bag itself. 
Table 2. Photosynthetically active radiation (PAR), ultraviolet A radiation (UVA), and ultraviolet B radiation (UVB) measured during the 9-day microcosm experiment. Values are shown for the incident irradiance and the estimated irradiance under the high light (HL) and low light (LL) treatments (i.e. values corrected for the transmission through the incubation bags). PAR values were averaged over a day whereas UVA and UVB were measured each day around noon between T5 and T9 only due to instrument dysfunction during the first 4 days.

\begin{tabular}{|c|c|c|c|c|c|c|c|c|c|c|}
\hline & & \multicolumn{3}{|c|}{$\begin{array}{c}\text { PAR } \\
\left(\mu \mathrm{mol} \text { quanta } \mathrm{m}^{-2} \mathrm{~s}^{-1}\right)\end{array}$} & \multicolumn{3}{|c|}{$\begin{array}{c}\mathrm{UV}-\mathrm{A} \\
\left(\mathrm{W} \mathrm{m}^{-2}\right)\end{array}$} & \multicolumn{3}{|c|}{$\begin{array}{c}\mathrm{UV}-\mathrm{B} \\
\left(\mathrm{W} \mathrm{m}^{-2}\right)\end{array}$} \\
\hline & & Incident & HL & $\mathrm{LL}$ & Incident & HL & LL & Incident & HL & LL \\
\hline Time & $\mathrm{T} 1$ & 189 & 146 & 61 & & & & & & \\
\hline (day) & $\mathrm{T} 2$ & 216 & 168 & 70 & & & & & & \\
\hline & $\mathrm{T} 3$ & 333 & 258 & 109 & & & & & & \\
\hline & $\mathrm{T} 4$ & 402 & 312 & 131 & & & & & & \\
\hline & T5 & 394 & 306 & 129 & 13 & 7.8 & 2.6 & 0.37 & 0.12 & \\
\hline & T6 & 381 & 270 & 124 & 4.6 & 2.8 & 0.94 & 0.2 & 0.07 & \\
\hline & $\mathrm{T} 7$ & 348 & 304 & 113 & 12 & 7.6 & 2.5 & 0.37 & 0.12 & \\
\hline & $\mathrm{T} 8$ & 392 & 304 & 128 & 10 & 6.2 & 2.1 & 0.36 & 0.12 & \\
\hline & T9 & 272 & 211 & 89 & 4.9 & 3 & 1 & 0.17 & 0.06 & \\
\hline
\end{tabular}

\subsection{Microcosm subsampling for chemical and biological variables}

The 12 incubation bags (microcosms) were monitored over 9 days after the initial acidification (T0). Subsampling took place at 9:00 LT the first day (T0), before the initial acidification, and between 6:00 and 10:00 LT for the 9 following days (T1-T9). Not all the variables were sampled every day. Water for $\mathrm{pH}, \mathrm{TA}$, dissolved inorganic carbon (DIC), and DMS analyses was collected directly from the microcosms to minimise outgassing, whereas water for the measurement of chlorophyll $a(\mathrm{Chl} a)$, nutrients, flow cytometry, and taxonomy was first collected in a brown bottle $\left(\right.$ Nalgene $\left.{ }^{\circledR}, 1 \mathrm{~L}\right)$ and kept at $4{ }^{\circ} \mathrm{C}$ in the refrigerator until subsampling, generally $2 \mathrm{~h}$ after initial water sampling. Water for salinity determination was taken at T0 before the acidification process and at T9 in each incubation bag. Samples for salinity were stored in the dark in $250 \mathrm{~mL}$ plastic bottles until analysis in May 2016 using a Guidelines 8400B salinometer. At least half of the initial volume of the microcosms $(5 \mathrm{~L})$ remained in the bags at the end of the experiment.

\subsubsection{Carbonate system}

The $\mathrm{pH}$ was measured on $\mathrm{T} 1, \mathrm{~T} 2, \mathrm{~T} 4, \mathrm{~T} 6, \mathrm{~T} 8$, and $\mathrm{T} 9$ using an Agilent $8453 \mathrm{UV}$-visible Spectrophotometer on the total hydrogen ion scale $\left(\mathrm{pH}_{\mathrm{T}}\right)$. Water was directly subsampled from the incubation bags to the spectrophotometric cells in order to minimise gas exchange with ambient air. The spectrophotometer cells $(10 \mathrm{~cm}$ path length, $V=33 \mathrm{~mL})$ were brought up to $25^{\circ} \mathrm{C}$ in an aluminum block before readings on the spectrophotometer (approximately $1 \mathrm{~h}$ after sampling). Absorbance was measured at 434,578 , and $730 \mathrm{~nm}$ before and after addition of $50 \mu \mathrm{L}$ of a $m$-cresol purple indicator dye solution (Clayton and Byrne, 1993). A second addition of $50 \mu \mathrm{L}$ of $m$-cresol purple indicator dye solution was made to the sample in order to determine the extent of the dye perturbation on $\mathrm{pH}_{\mathrm{T}}$ values. Duplicates were analysed for each incubation bag, and $\mathrm{pH}_{\mathrm{T}}$ was subsequently calculated according to Dickson et al. (2007, see their section SOP 6b). Data were then converted to mean incubation temperature using $\mathrm{CO}_{2}$ SYS and the TA measurements (Pierrot et al., 2006). The $p \mathrm{CO}_{2}$ values corresponding to each $\mathrm{pH}_{\mathrm{T}}$ measurement were also calculated using $\mathrm{CO}_{2} \mathrm{SYS}$ software. Concentrations in protons for each microcosm were calculated using the $\mathrm{pH}_{\mathrm{T}}$ measurements.

Water for TA and DIC analyses was subsampled early in the morning on days T1, T4, and T9. Water was gently collected from the incubation bags in pre-rinsed $250 \mathrm{~mL}$ glass bottles. Samples were analysed on board within $4 \mathrm{~h}$ by coulometric and potentiometric titration for DIC and TA, respectively (more details are given in, for example, Johnson et al., 1993, or Dickson et al., 2007), using a VINDTA 3C (Versatile Instrument for the Determination of Titration Alkalinity, Marianda). Both the DIC and TA measurements were calibrated against certified reference materials (CRMs, Andrew Dickson, Scripps Institution of Oceanography, USA) and the reproducibility was better than 1 and $2 \mu \mathrm{mol} \mathrm{kg}{ }^{-1} \mathrm{SW}$, respectively, for the DIC and TA measurements.

\subsubsection{Nutrients}

Water for nutrient analysis was filtered through Luer-lock syringe Acrodisc filters (glass microfiber, GMF, - porosity of $0.7 \mu \mathrm{m}$ ) into $15 \mathrm{~mL}$ acid-washed polyethylene tubes. After collection, samples were stored at $4{ }^{\circ} \mathrm{C}$ in the dark and analysed within $1 \mathrm{~h}$ for nitrate $\left(\mathrm{NO}_{3}^{-}\right)$as well as nitrite $\left(\mathrm{NO}_{2}^{-}\right)$, silicic acid $\left(\mathrm{Si}(\mathrm{OH})_{4}\right)$, and soluble reactive phosphate (SRP) on a Bran and Luebbe Autoanalyser III using a colorimetric method adapted from Hansen and Koroleff (2007) (detection limits for $\mathrm{NO}_{3}^{-}: 0.03 \mu \mathrm{mol} \mathrm{L}-1, \mathrm{NO}_{2}^{-}: 0.02 \mu \mathrm{mol} \mathrm{L}-1$, $\mathrm{Si}(\mathrm{OH})_{4}: 0.1 \mu \mathrm{mol} \mathrm{L}^{-1}$, and SRP: $\left.0.05 \mu \mathrm{mol} \mathrm{L}^{-1}\right)$. 


\subsubsection{Plankton biomass and enumeration}

Water for Chl $a$ concentration analysis was subsampled from each incubation bag every day using $1 \mathrm{~L}$ brown polyethylene bottles. The bottles were stored at $4{ }^{\circ} \mathrm{C}$ in the dark for $2 \mathrm{~h}$ before filtration onto $25 \mathrm{~mm}$ Whatman GF/F filters $(0.7 \mu \mathrm{m}$ nominal pore size). Phytoplankton pigments were extracted in $90 \%$ acetone and stored at $4{ }^{\circ} \mathrm{C}$ in the dark for $20 \mathrm{~h}$. The fluorescence of the extracted pigments was then measured using a Turner Designs 10AU fluorometer after acidification according to the method described by Parsons et al. (1984). Chl $a$ concentrations were calculated from the equation published in Holm-Hansen et al. (1965).

For the enumeration of phytoplankton $(\leq 20 \mu \mathrm{m})$ and bacteria, sterile cryogenic polypropylene vials were filled with $4 \mathrm{~mL}$ of water to which $20 \mu \mathrm{L}$ of glutaraldehyde (Grade I, $25 \%$ in water, Sigma Aldrich; Marie et al., 2005) was added. Duplicate samples were flash frozen in liquid nitrogen after standing for $15 \mathrm{~min}$ at room temperature in the dark. These samples were then stored at $-80^{\circ} \mathrm{C}$ for 5 months until flow cytometry analysis. After defrosting to ambient air temperature, samples were analysed using a FASC Calibur FCB3 flow cytometer (Becton Dickinson). One of the duplicate samples was used to determine the abundance of picophytoplankton $(0.2-2 \mu \mathrm{m})$ (which include pico-eukaryotes and pico-cyanobacteria) and nano-phytoplankton $(2-20 \mu \mathrm{m})$ based on theirs autofluorescence characteristics and size (Marie et al., 2005). The other tube was used for bacterial counts (Marie et al., 1999).

On days T0, T5, and T9, water samples (between 100 and $250 \mathrm{~mL}$ depending on the biomass) were taken for identification and counting of eukaryotic cells (protists) larger than $2 \mu \mathrm{m}$. Samples were preserved in acidic Lugol's solution (Parsons et al., 1984) and stored in the dark for 7 months until enumeration with an inverted microscope (WILD Heerbrugg) equipped with phase contrast optics (Lund et al., 1958). A total of 13 selected samples, collected under both light treatments and representing the whole range of $\mathrm{pH}$ amendments (i.e. $\mathrm{pH}_{\mathrm{T}} 8.1$ (control), 7.6, and 7.2), were counted.

\subsubsection{Fast-repetition-rate fluorometry (FRRF) measurements}

For FRRF measurements, $20 \mathrm{~mL}$ of seawater was taken directly from the microcosms at $\mathrm{pH}_{\mathrm{T}} 8.1,7.8$, and 7.2 for both HL and LL treatments on days T2, T4, T6, T7, and T9. Water was subsampled early in the morning in order to avoid photoinhibition (Schuback et al., 2015). The FRRF measurements were conducted on a benchtop FRRF instrument (Soliense Inc.), as described in Schuback et al. (2015). For each sample, background fluorescence blanks were prepared by syringe filtering a small amount of water through a Whatman GF/F filter. Samples were kept at very low light (approx. $5 \mu \mathrm{mol}$ quanta $\mathrm{m}^{-2} \mathrm{~s}^{-1}$ ) at in situ temperature for $45 \mathrm{~min}$ be- fore the measurements. A single turnover (ST) excitation protocol was applied to derive minimum $\left(F_{\mathrm{O}}\right)$ and maximum $\left(F_{\mathrm{m}}\right)$ chlorophyll $a$ fluorescence yields by applying an iterative nonlinear fitting procedure to a mean of 20 consecutive ST flashlet sequences using custom software (Kolber et al., 1998). The $F_{\mathrm{o}}$ and $F_{\mathrm{m}}$ were used to calculate $F_{\mathrm{v}} / F_{\mathrm{m}}$ as $\left(F_{\mathrm{m}}-F_{\mathrm{o}}\right) / F_{\mathrm{m}}$. In the absence of iron limitation, this ratio can be used as a sensitive indicator of algal photosynthetic efficiency (Maxwell and Johnson, 2000; Schuback et al., 2016).

\subsubsection{DMSP and DMS concentrations}

For the quantification of dissolved DMSP $\left(\mathrm{DMSP}_{\mathrm{d}}\right), 20 \mathrm{~mL}$ of the water sample was gravity-filtered through $47 \mathrm{~mm}$ Whatman GF/F filters and the first $3.5 \mathrm{~mL}$ of filtrate was stored in $5 \mathrm{~mL}$ polyethylene tubes using the less disruptive small-volume gravity drip filtration (SVDF) method described by Kiene and Slezak (2006). Tubes for total DMSP $\left(\mathrm{DMSP}_{\mathrm{T}}\right)$ samples were directly filled with $3.5 \mathrm{~mL}$ of unfiltered water. Samples of both $\mathrm{DMSP}_{\mathrm{d}}$ and $\mathrm{DMSP}_{\mathrm{T}}$ were preserved by adding $50 \mu \mathrm{L}$ of a $50 \%$ sulfuric acid $\left(\mathrm{H}_{2} \mathrm{SO}_{4}\right)$ solution to the $5 \mathrm{~mL}$ tubes, which were then stored at $4{ }^{\circ} \mathrm{C}$ in the dark until analysis in the laboratory. DMSP concentrations were determined as DMS through hydrolysis with a $5 \mathrm{~N}$ solution of $\mathrm{NaOH}$, purging and cryo-trapping in liquid nitrogen, followed by analysis on a Varian 3800 Gas Chromatograph equipped with a pulsed flame photometric detector (PFPD, Varian 3800) with a detection limit of $0.1 \mathrm{nmol} \mathrm{L}^{-1}$ (Scarratt et al., 2000; Lizotte et al., 2012; Galindo et al., 2016). All DMSP samples were calibrated against multiple micro-injections of a $100 \mathrm{nmol} \mathrm{L}^{-1}$ solution of standardised dimethyl-B-propiothetin (DMPT from Research Plus) hydrolysed with a $5 \mathrm{~N}$ solution of $\mathrm{NaOH}$.

Water samples for DMS concentration analysis were withdrawn on days T0, T2, T4, and every day for the remainder of the incubation period. DMS concentrations were determined on-board the ship using purging, trapping, and S-specific gas chromatography, as described by Asher et al. (2015). The custom-built system described by Asher et al. (2015) was used here in manual mode by directly injecting $10 \mathrm{~mL}$ of each incubation sample into a sparge vessel. Water for DMS analysis was subsampled directly from each bag using a Luer-lock syringe and injected into the custom-built system at most $40 \mathrm{~min}$ after sampling. Ultra-high-purity $\mathrm{N}_{2}$ was used to extract the volatile DMS from solution at a flow rate of $100 \mathrm{~mL} \mathrm{~min}^{-1}$. The sparged DMS was adsorbed onto Carbopack-X packed in a stainless steel trap. After trapping was completed, a series of high current pulses heated the trap to $250{ }^{\circ} \mathrm{C}$ to desorb the DMS onto the capillary column prior to elution and detection by a pulsed flame photometric detector (OI Analytical, Model 5380). Light emitted during combustion in the PFPD was converted to a voltage (using a PMT - photomultiplier tube) and recorded by the LabView software. Raw data outputs (peak voltages) were processed using MATLAB by calculating the area under each curve and by 
comparing them to standard curves to give final DMS concentrations. Known DMS concentrations of 0, 3, 6, 9, 12, and $15 \mathrm{nmol} \mathrm{L}^{-1}$ were processed for calibration purposes before each sampling day in order to obtain the standard curves. Area under each standard curve was calculated using MATLAB and associated with its known DMS concentration.

\subsection{Statistical analysis}

All statistical analyses were run using RStudio (http://www. rstudio.com/). Normality of the data was determined using a Shapiro-Wilk test at the 0.05 significance level and data were transformed (log or square root) when the normality was rejected $(p<0.05)$. To test for differences between $\mathrm{pH}$ and light treatments for the variables measured during the experiment (time series of nutrient and Chl $a$ concentrations, phytoplankton, bacteria abundances, and dimethylated compound concentrations), we used a generalized least-square model that corrected for data autocorrelation due to time repetition (gls command in $\mathrm{R}$ studio, package nlme; also see the method described by Paul et al., 2016). In the model, time and $\mathrm{pH}$ were taken as two continuous factors; the light was included as a categorical factor (two levels: low light, high light). As the inclusion of the interaction between light and $\mathrm{pH}$ in our gls model did not yield significant results, it was not included in our statistical analysis. Relationships between the average values of all response variables and the set of $\mathrm{pH}_{\mathrm{T}}$ were evaluated using the Pearson's linear regression $\left(r^{2}\right)$.

\section{Results}

\subsection{Irradiance conditions}

Daily mean incident PAR varied between 189 and $492 \mu \mathrm{mol} \mathrm{m}^{-2}$ quanta $^{-1}$ during the 9 days of the incubation. Accordingly, daily mean PAR in the HL and LL treatment varied between 146 and $312 \mu \mathrm{mol} \mathrm{m}^{-2}$ quanta $\mathrm{s}^{-1}$ and between 61 and $131 \mu \mathrm{mol} \mathrm{m} \mathrm{m}^{-2}$ quanta $\mathrm{s}^{-1}$, respectively (Table 2). Incident UVA and UVB levels varied respectively between 4 and $13 \mathrm{~W} \mathrm{~m}^{-2}$, and between 0.1 to $0.3 \mathrm{~W} \mathrm{~m}^{-2}$ during the last 5 days of the experiment.

\subsection{State of the carbonate system}

Table 1 summarises values of four carbonate system parameters and associated proton concentrations $\left(\mathrm{pH}_{\mathrm{T}},\left[\mathrm{H}^{+}\right]\right.$, DIC, TA, $p \mathrm{CO}_{2}$ ) for each light and $\mathrm{pH}$ treatment at T0, T1, T4, and T9. At T1, the mean TA in the acidified bags was $2221 \pm 16 \mu \mathrm{mol} \mathrm{kg}^{-1} \mathrm{SW}$, approximately $1 \%$ lower than the value of $2243 \mu \mathrm{mol} \mathrm{kg}{ }^{-1} \mathrm{SW}$ measured in the original sample recovered from $38 \mathrm{~m}$ depth at station BB-3. At the beginning of the experiment (T1), the mean $\mathrm{pH}_{\mathrm{T}}$ at $4.27^{\circ} \mathrm{C}$ (mean incubator temperature during the experiment) between HL and LL controls was 7.939 \pm 0.003 (see Table 1 and

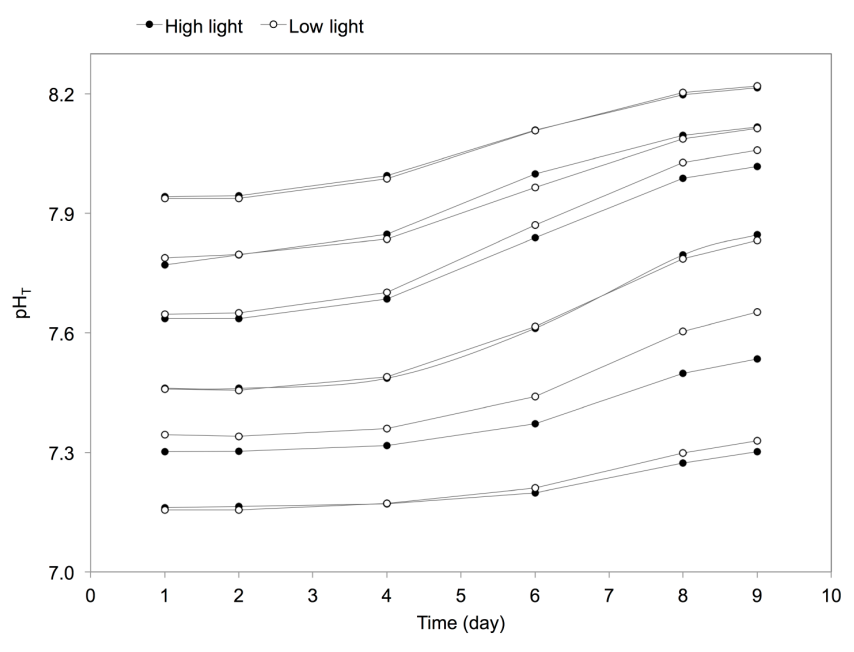

Figure 2. Temporal variations in $\mathrm{pH}_{\mathrm{T}}$ (total hydrogen ion scale) during the microcosm experiment. Black and white circles represent the $\mathrm{pH}$ gradient in the high light (HL) and low light (LL) treatments, respectively.

Fig. 2). Values for the following decreasing $\mathrm{pH}$ levels were $7.779 \pm 0.012,7.641 \pm 0.007,7.460 \pm 0.001,7.323 \pm 0.030$, and $7,159 \pm 0.004$. As expected, the $\mathrm{pH}_{\mathrm{T}}$ in all bags increased during the incubation period due to photosynthesis (Rost et al., 2008; Paul et al., 2016) (mean protons change per bag of $-1.52 \times 10^{-8} \pm 6.67 \times 10^{-9} \mathrm{~mol} \mathrm{~L}^{-1}$ over the 9day experiment; Fig. 2). A difference in $\mathrm{pH}_{\mathrm{T}}$ (corresponding to an average proton difference of $-8.87 \times 10^{-9} \pm 8.59 \times$ $10^{-9} \mathrm{~mol} \mathrm{~L}^{-1}$ ) was still observed at $\mathrm{T} 9$ between bags in both the LL and HL treatments (Fig. 2). The $\mathrm{pH}_{\mathrm{T}}$ gradients between the two light treatments were thus very similar, allowing us to clearly discriminate between $\mathrm{pH}_{\mathrm{T}}$ and light effects. Hereafter, we refer to the $\mathrm{pH}$ treatments by their mean $\mathrm{pH}_{\mathrm{T}}$ values measured over the 9 incubation days: 8.1 (control) and decreasing mean $\mathrm{pH}_{\mathrm{T}}$ values of 7.9, 7.8, 7.6, 7.4, and 7.2.

\subsection{Dissolved inorganic nutrient concentrations}

At $\mathrm{T} 1, \mathrm{NO}_{3}^{-}, \mathrm{Si}(\mathrm{OH})_{4}$, and $\mathrm{SRP}$ concentrations varied between 5.07-5.83, 8.87-10.45, and $0.94-1.00 \mu \mathrm{mol} \mathrm{L}^{-1}$, respectively (Fig. 3). All three nutrients displayed the same general temporal pattern during the incubation, irrespective of the light treatment. Their concentrations remained constant or increased slightly during the first 3 days and then decreased rapidly with the onset of the bloom to very low or undetectable concentrations between $\mathrm{T} 6$ and $\mathrm{T} 8$ for $\mathrm{NO}_{3}^{-}$ $\left(\right.$ all $\mathrm{pH}_{\mathrm{T}}$ ) and at $\mathrm{T} 8$ for $\mathrm{Si}(\mathrm{OH})_{4}$ (highest $\mathrm{pH}_{\mathrm{T}}$ only). Likewise, SRP concentrations decreased in parallel with $\mathrm{NO}_{3}^{-}$ and $\mathrm{Si}(\mathrm{OH})_{4}$, but remained higher than $0.3 \mu \mathrm{mol} \mathrm{L}{ }^{-1}$ during the whole experiment. The impact of $\mathrm{pH}$ on nutrient consumption was apparent under both light treatments, with nutrients being generally consumed more rapidly at high $\mathrm{pH}_{\mathrm{T}}$ than at low $\mathrm{pH}_{\mathrm{T}}$ (Fig. 3, Table 3). The $\mathrm{NO}_{3}^{-}$depletion was 

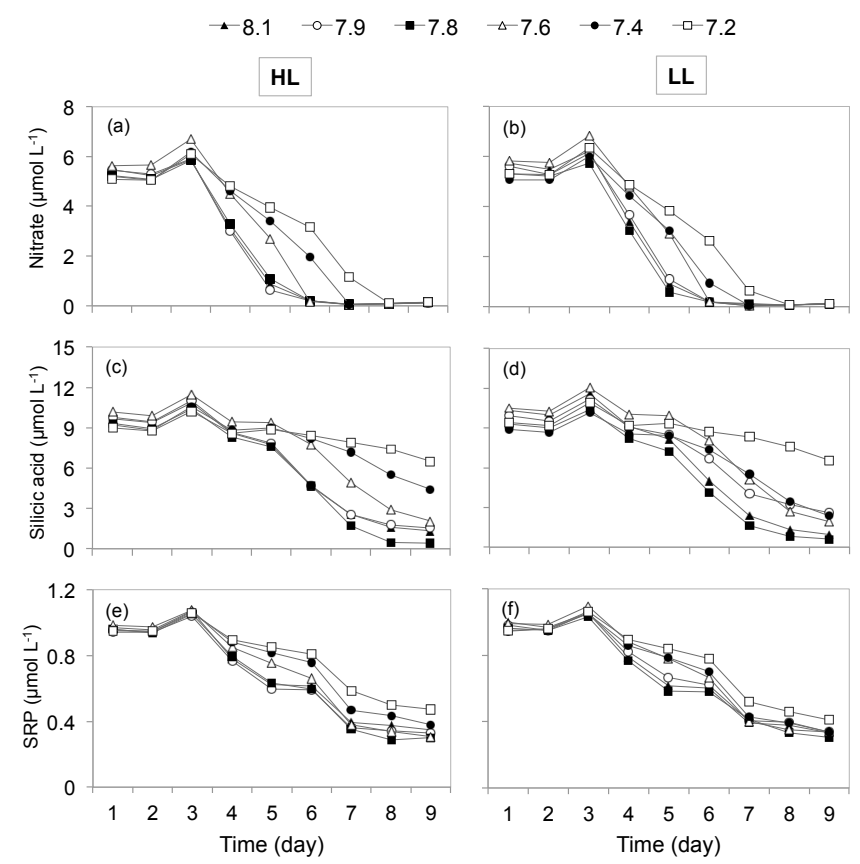

Figure 3. Temporal variations in (a, b) nitrate, (c, d) silicic acid, and $(\mathbf{e}, \mathbf{f})$ soluble reactive phosphate (SRP) concentrations during the experiment. Left and right panels show variations under the high light (HL) and low light (LL) treatments, respectively. Each curve represents a microcosm identified by its mean $\mathrm{pH}_{\mathrm{T}}$ value.

temporally delayed in the most acidified treatments, reaching below detection values 1 day after the other treatments for microcosms at $\mathrm{pH}_{\mathrm{T}} 7.4$ (T7) and 2 days after the others for microcosms at $\mathrm{pH}_{\mathrm{T}} 7.2$ (T8). With the exception of microcosms at $\mathrm{pH}_{\mathrm{T}} 8.1$ under $\mathrm{LL}$, and at $\mathrm{pH}_{\mathrm{T}} 7.8$ under both light treatments, $\mathrm{Si}(\mathrm{OH})_{4}$ remained at relatively high concentrations in all treatments after the peak of the bloom (Figs. 3c, d and 4a, b). While the ratio of $\mathrm{NO}_{3}^{-}$to SRP uptake $\left(\Delta \mathrm{NO}_{3}^{-}: \Delta \mathrm{SRP}\right)$ during the incubation showed no statistical difference between the six $\mathrm{pH}_{\mathrm{T}}$ treatments tested, the ratio $\Delta \mathrm{Si}(\mathrm{OH})_{4}: \Delta \mathrm{NO}_{3}^{-}$decreased linearly with increasing proton concentration for both light regimes $\left(r^{2}=0.72, p<0.001\right.$; data not shown). This change was driven mostly by a reduction in $\mathrm{Si}(\mathrm{OH})_{4}$ uptake, which exhibited a ca. 3-fold difference between experimental $\mathrm{pH}$ extremes compared to a ca. 1.7-fold difference for $\Delta \mathrm{NO}_{3}^{-}$uptake (not shown).

\subsection{Phytoplankton biomass}

The mean Chl $a$ concentration before the beginning of the experiment (T0) was $0.686 \pm 0.004 \mu \mathrm{g} \mathrm{L}^{-1}$, and increased exponentially from $\mathrm{T} 1$ to $\mathrm{T} 5-\mathrm{T} 8$, depending on the $\mathrm{pH}_{\mathrm{T}}$ treatment, to reach maximum values varying between 4.5 and $7.5 \mu \mathrm{g} \mathrm{L}{ }^{-1}$ (Fig. 4a, b). The bloom period was followed by either a plateau or a small decrease in Chl $a$ biomass. The temporal changes in $\mathrm{Chl} a$ concentrations were not affected by the light regimes but we observed a significant
Table 3. Overview of the results of generalized least-square models testing for the effects of time, light, and $\mathrm{pH}_{\mathrm{T}}$ over the duration of the incubation on nitrate, silicic acid, soluble reactive phosphate (SRP), chlorophyll $a$, dissolved DMSP, total DMSP, and DMS concentrations, as well as nano-phytoplankton, pico-phytoplankton, and bacterial abundances. Type of transformations applied to data when necessary are indicated in parentheses, significant results are indicated in bold, DF is the degrees of freedom, and $p$ is the significance of the $t$-value.

\begin{tabular}{|c|c|c|c|c|}
\hline Response variable & Factor & $\mathrm{DF}$ & $t$-value & $p$ \\
\hline \multirow{3}{*}{$\begin{array}{l}\text { Nitrate } \\
\left(\mu \mathrm{mol} \mathrm{L}^{-1}\right)\end{array}$} & Time & 77 & -7.853 & $<0.001$ \\
\hline & Light & 77 & -0.395 & 0.693 \\
\hline & $\mathrm{pH}$ & 77 & -5.156 & $<0.001$ \\
\hline \multirow{3}{*}{$\begin{array}{l}\text { Silicic acid } \\
\left(\mu \mathrm{mol} \mathrm{L}^{-1}\right)\end{array}$} & Time & 108 & -8.308 & $<0.001$ \\
\hline & Light & 108 & 0.123 & 0.903 \\
\hline & $\mathrm{pH}$ & 108 & -6.608 & $<0.001$ \\
\hline \multirow{3}{*}{$\begin{array}{l}\text { (sqrt) SRP } \\
\left(\mu \mathrm{mol} \mathrm{L} \mathrm{L}^{-1}\right)\end{array}$} & Time & 108 & -8.487 & $<0.001$ \\
\hline & Light & 108 & -1.826 & 0.071 \\
\hline & $\mathrm{pH}$ & 108 & -6.915 & $<0.001$ \\
\hline \multirow{3}{*}{$\begin{array}{l}\text { (sqrt) Chlorophylla } \\
\left(\mu \mathrm{g} \mathrm{L}^{-1}\right)\end{array}$} & Time & 108 & 7.456 & $<0.001$ \\
\hline & Light & 108 & 0.151 & 0.880 \\
\hline & $\mathrm{pH}$ & 108 & 4.862 & $<0.001$ \\
\hline \multirow{3}{*}{$\begin{array}{l}\text { (sqrt) Nano-phytoplankton } \\
\text { (cells } \mathrm{mL}^{-1} \text { ) }\end{array}$} & Time & 107 & 17.614 & $<0.001$ \\
\hline & Light & 107 & -0.346 & 0.608 \\
\hline & $\mathrm{pH}$ & 107 & 6.513 & $<0.001$ \\
\hline \multirow{3}{*}{$\begin{array}{l}\text { (sqrt) Pico-phytoplankton } \\
\text { (cells } \mathrm{mL}^{-1} \text { ) }\end{array}$} & Time & 107 & 26.926 & $<0.001$ \\
\hline & Light & 107 & 1.388 & 0.185 \\
\hline & $\mathrm{pH}$ & 107 & 2.043 & 0.035 \\
\hline \multirow{3}{*}{$\begin{array}{l}\text { ( } 2 \text { outliers removed) Bacteria } \\
\text { (cells } \mathrm{mL}^{-1} \text { ) }\end{array}$} & Time & 104 & 4.300 & $<0.001$ \\
\hline & Light & 104 & 2.604 & 0.011 \\
\hline & $\mathrm{pH}$ & 104 & 3.167 & $<0.01$ \\
\hline \multirow{3}{*}{$\begin{array}{l}\text { Total DMSP } \\
\left(\mathrm{nmol} \mathrm{L}^{-1}\right)\end{array}$} & Time & 108 & 1.562 & 0.121 \\
\hline & Light & 108 & 0.950 & 0.344 \\
\hline & $\mathrm{pH}$ & 108 & 2.070 & 0.041 \\
\hline \multirow{3}{*}{ 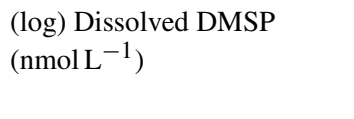 } & Time & 60 & 2.529 & 0.014 \\
\hline & Light & 60 & -0.753 & 0.454 \\
\hline & $\mathrm{pH}$ & 60 & 0.362 & 0.718 \\
\hline \multirow{3}{*}{$\begin{array}{l}\text { (sqrt) DMS } \\
(\text { nmol L } \\
-1)\end{array}$} & Time & 77 & 2.478 & 0.015 \\
\hline & Light & 77 & 0.387 & 0.700 \\
\hline & $\mathrm{pH}$ & 77 & 6.635 & $<0.001$ \\
\hline
\end{tabular}

difference in $\mathrm{Chl} a$ concentrations between $\mathrm{pH}_{\mathrm{T}}$ treatments (Table 3). Figure 5a shows the relationship between the mean $\mathrm{Chl} a$ concentrations and the corresponding mean proton concentrations over the entire experimental period. For both light regimes (data pooled), the mean $\mathrm{Chl} a$ concentration decreased linearly with increasing proton concentration (Fig. 5a, Table 4). 
Table 4. Empirical relationships of various biological or chemical (response) variables with proton concentration $\left(\mathrm{mol} \mathrm{L}^{-1}\right)$. Values are the means of all the microcosms. Linear regressions were performed on both light treatments when light had a significant effect on the response variable (see Table 3). Significant results are in bold, DF is the degrees of freedom, $r^{2}$ is the squared Pearson correlation coefficient between proton concentration and the response variable, and $p$ is the significance of each parameters of the regression.

\begin{tabular}{|c|c|c|c|c|c|}
\hline Response variable & DF & $r^{2}$ & Parameters & & $p$ \\
\hline Mean Chlorophyll $a\left(\mu \mathrm{g} \mathrm{L}^{-1}\right)$ & 10 & 0.86 & $\begin{array}{l}\text { slope } \\
\text { intercept }\end{array}$ & $\begin{array}{r}-2.70 \times 10^{7} \\
3.95\end{array}$ & $\begin{array}{l}<0.001 \\
<0.001\end{array}$ \\
\hline Mean nano-phytoplankton (cells $\mathrm{mL}^{-1}$ ) & 10 & 0.73 & $\begin{array}{l}\text { slope } \\
\text { intercept }\end{array}$ & $\begin{array}{r}-4.37 \times 10^{10} \\
6.74 \times 10^{3}\end{array}$ & $\begin{array}{l}<0.001 \\
<0.001\end{array}$ \\
\hline Mean pico-phytoplankton (cells $\mathrm{mL}^{-1}$ ) & 10 & 0.32 & $\begin{array}{l}\text { slope } \\
\text { intercept }\end{array}$ & $\begin{array}{r}6.52 \times 10^{11} \\
6.73 \times 10^{4}\end{array}$ & $\begin{array}{r}0.056 \\
<0.001\end{array}$ \\
\hline Mean bacteria (cells $\mathrm{mL}^{-1}$ ) & & & & & \\
\hline High Light & 4 & 0.84 & $\begin{array}{l}\text { slope } \\
\text { intercept }\end{array}$ & $\begin{array}{r}-2.54 \times 10^{12} \\
9.77 \times 10^{5}\end{array}$ & $\begin{array}{r}<0.01 \\
<0.001\end{array}$ \\
\hline Low Light & 4 & 0.33 & $\begin{array}{l}\text { slope } \\
\text { intercept }\end{array}$ & $\begin{array}{r}-8.04 \times 10^{11} \\
1.01 \times 10^{6}\end{array}$ & $\begin{array}{r}0.23 \\
<0.001\end{array}$ \\
\hline Mean DMSP $\left(\mathrm{nmol} \mathrm{L}^{-1}\right)$ & 10 & 0.04 & $\begin{array}{l}\text { slope } \\
\text { intercept }\end{array}$ & $\begin{array}{r}-6.90 \times 10^{7} \\
3.81 \times 10^{1}\end{array}$ & $\begin{array}{r}0.55 \\
<0.001\end{array}$ \\
\hline Mean DMS $\left(\mathrm{nmol} \mathrm{L}^{-1}\right)$ & 10 & 0.9 & $\begin{array}{l}\text { slope } \\
\text { intercept }\end{array}$ & $\begin{array}{r}-1.19 \times 10^{8} \\
8.37\end{array}$ & $\begin{array}{l}<0.001 \\
<0.001\end{array}$ \\
\hline Mean DMS : DMSPd ratio & 10 & 0.57 & $\begin{array}{l}\text { slope } \\
\text { intercept }\end{array}$ & $\begin{array}{r}-1.02 \times 10^{8} \\
8.45\end{array}$ & $\begin{array}{r}<0.01 \\
<0.001\end{array}$ \\
\hline
\end{tabular}

\subsection{Phytoplankton abundance and taxonomy of the protist community $>2 \mu \mathrm{m}$}

Nano-phytoplankton (algal cells between 2 and $20 \mu \mathrm{m}$ ) abundance varied during the incubation from $0.81 \times$ $10^{3}$ cells $\mathrm{mL}^{-1}$ on day $\mathrm{T} 1$ to $19 \times 10^{3}$ cells $\mathrm{mL}^{-1}$, a maximal value reached at $\mathrm{pH}_{\mathrm{T}} 7.61$ on day $\mathrm{T} 8$ under LL conditions (Fig. 4c, d). For both light treatments, nano-phytoplankton abundance increased steadily from T1 to T6-T8 and decreased or remained stable thereafter. This trend is comparable with the trend observed for $\mathrm{Chl} a$ (Fig. 4a, b) but with the slight difference that the nano-phytoplankton generally reached their maximal abundance 1-2 days after the Chl $a$ concentration maxima. The lag probably reflects a decrease in Chl $a$ synthesis (and thus Chl $a$ cell quota) as the dividing cells were becoming nitrogen-limited. Variations in nanophytoplankton abundance were significantly correlated with Chl $a$ during the growth phase $\left(r^{2}=0.78, p<0.001\right)$, suggesting that nano-phytoplankton were responsible for most of the biomass build-up during the bloom. Like Chl $a$, only the $\mathrm{pH}_{\mathrm{T}}$ gradient (not light treatment) appeared to have affected nano-phytoplankton dynamics as we observed significant differences between nano-phytoplankton abundances between all $\mathrm{pH}_{\mathrm{T}}$ tested (Table 3). As shown in Fig. 5b, the mean nano-phytoplankton abundances decreased as the proton concentration increased (data pooled, Table 4).

The initial protist community $>2 \mu \mathrm{m}$ was dominated by centric diatoms (33\% of total protist abundance), followed by Cryptophyceae $(22 \%)$, unidentified flagellates $(17 \%)$, and Prasinophyceae (12\%) (Fig. 6). Pennate diatoms, Dino- phyceae, and Chrysophyceae were also present in smaller proportions $(4,3$, and $2 \%$ respectively; included in the group named "others" in Fig. 6, given their low abundance). Among the protists $>2 \mu \mathrm{m}$, centric diatoms were dominant in most treatments at $\mathrm{T} 5$ and $\mathrm{T} 9$, accounting for between 72 and $89 \%$ of total cells, while the other groups initially presented decreased abundance or became undetectable. More than $90 \%$ of the centric diatoms belonged to the genus Chaetoceros. Although the dominant species of Chaetoceros could not be identified (the biomass of this genus was dominated by unidentified Chaetoceros comprised between 2 and $5 \mu \mathrm{m}$ ), Chaetoceros gelidus, Chaetoceros wighamii, Chaetoceros cf. karianus, and Chaetoceros teniussimus also contributed to the bloom. All microcosms subsampled during the experiment showed very similar taxonomic compositions, with Chaetoceros spp. dominating the community and accounting for more than $65 \%$ of cell abundance. The sole exception was the LL control microcosm $\left(\mathrm{pH}_{\mathrm{T}}\right.$ of 8.1$)$, in which the species composition on day $\mathrm{T} 9$ was more evenly distributed, with $58 \%$ of cell abundance attributed to groups other than centric diatoms. Within this fraction, flagellates accounted for $24 \%$ of the total abundance, Choanoflagellates for $12 \%$, Prasinophyceae for $10 \%$, Cryptophyceae for $2 \%$, and minority protist groups ("others") for $11 \%$. Due to the low number of samples analysed by inverted microscopy, it was not possible to statistically confirm whether the difference observed on day T9 between the control microcosm and the two other microcosms analysed was related to the $\mathrm{pH}$ gradient or resulted from inter-microcosm variability. Never- 

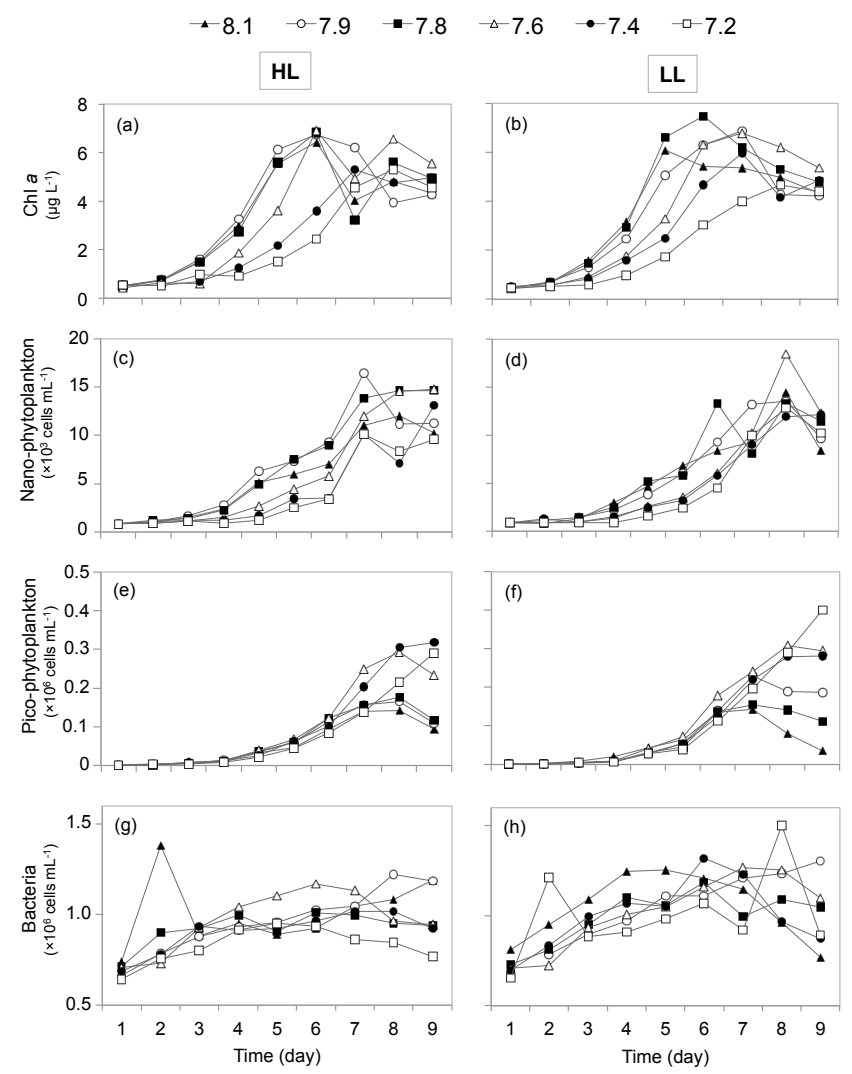

Figure 4. Temporal variations in (a, b) chlorophyll $a$ (Chl $a$ ) concentration, (c, d) nano-phytoplankton, (e, f) pico-phytoplankton, and $(\mathbf{g}, \mathbf{h})$ bacteria during the microcosm experiment. Left and right panels show variations under the high light (HL) and low light (LL) treatments, respectively. Each curve represents a microcosm identified by its mean $\mathrm{pH}_{\mathrm{T}}$ value.

theless, the general trends visible in Fig. 6 suggest that the relative abundance of each protist group was not influenced by the light regime or the $\mathrm{pH}$ gradient. Centric diatoms, and especially Chaetoceros spp., remained the dominant taxa throughout the incubation period in every microcosm. Dinophyceae, which initially contributed up to $3 \%$ of the protist abundance, became undetectable in all microcosms, including the controls, suggesting a negative effect of bag manipulation and the incubation process on this taxon during the experiment.

During the present experiment, pico-phytoplankton (algal cells between 0.2 and $2 \mu \mathrm{m}$ ) accounted for more than $90 \%$ of total phytoplankton cells $\leq 20 \mu \mathrm{m}$. Photosynthetic pico-cyanobacteria made up $\leq 2 \%$ of total abundance of pico-phytoplankton (i.e. pico-cyanobacteria + photosynthetic pico-eukaryotes). Pico-phytoplankton cell abundance was low at the start of the experiment $\left(<5 \times 10^{3}\right.$ cells $\left.\mathrm{mL}^{-1}\right)$ and remained at this low level until $\mathrm{T} 3$ when it began to increase to reach maximum concentrations (200$300 \times 10^{3}$ cells $\mathrm{mL}^{-1}$ ) between $\mathrm{T} 7$ and $\mathrm{T} 8$, depending on the $\mathrm{pH}_{\mathrm{T}}$ (Fig. 4e, f). Exceptions to this trend are the two micro-
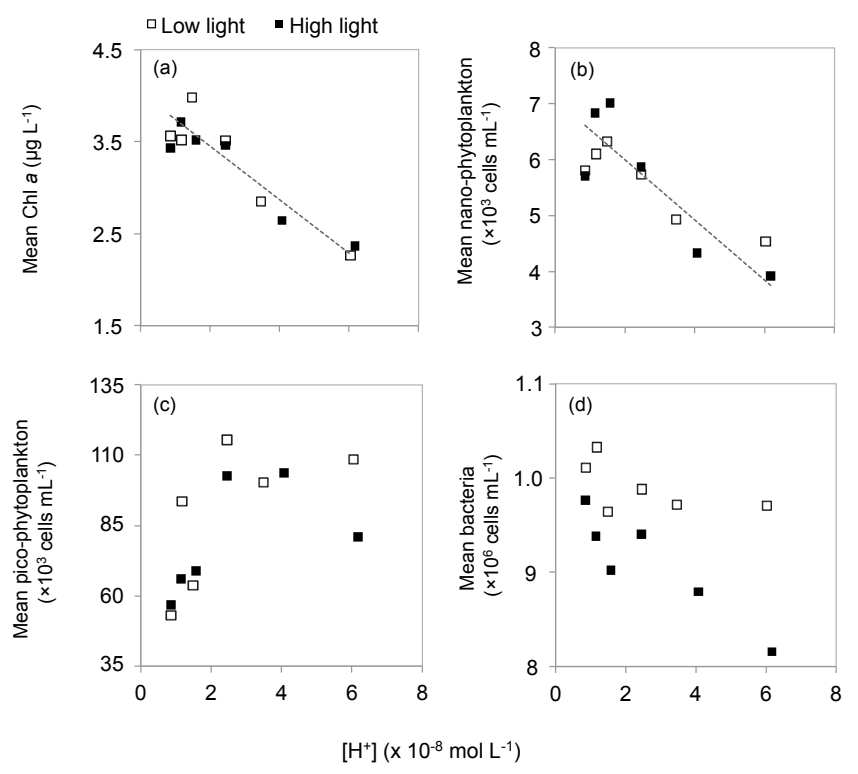

Figure 5. Relationships between the mean proton concentration values $\left(\left[\mathrm{H}^{+}\right]\right)$and (a) mean Chlorophyll $a(\mathrm{Chl} a)$, (b) mean nanophytoplankton abundance, (c) mean pico-phytoplankton abundance, and (d) mean bacteria abundance. Values are the means over the duration of the incubation in each microcosm. Significant regressions are shown with dashed lines, details of which are given in Table 4. Regressions were based on the full dataset when no significant difference between the light treatments was detected (see also Table 3 for more details).

cosms at the lowest $\mathrm{pH}_{\mathrm{T}}$ under both light regimes, in which pico-phytoplankton abundance continued to increase linearly until the end of the experiment. Of the two stressors tested (light and $\mathrm{pH}$ ), only $\mathrm{pH}_{\mathrm{T}}$ had a weak but significant effect on pico-phytoplankton abundances (Table 3). As shown in Fig. 5c, mean pico-phytoplankton abundance increased with increasing proton concentration for both light treatments, although this relation does not appear to be linear (data pooled in Table 4).

\subsection{Photosynthetic performance}

The $F_{\mathrm{v}} / F_{\mathrm{m}}$ ratio, a parameter widely used to indicate the photosynthetic performance of primary producers, was very similar between the two light treatments at each sampling day (Table 5). On days $\mathrm{T} 2$ and $\mathrm{T} 4, F_{\mathrm{v}} / F_{\mathrm{m}}$ ratios around 0.5 under both light treatments and at $\mathrm{pH}_{\mathrm{T}}$ values of 8.1, 7.8 and 7.2 were recorded, suggesting that the blooming algal cells were in good physiological condition. The ratios then decreased to ca. $0.3-0.4$ between days $\mathrm{T} 6$ and T9, when $\mathrm{NO}_{3}^{-}$started to be exhausted in most microcosms and the increase in Chl $a$ biomass and phytoplankton cell abundance had stopped (Figs. 3a, b and 4a-f). These results show low photosynthetic performance in the microcosms at the end of the experiment. 


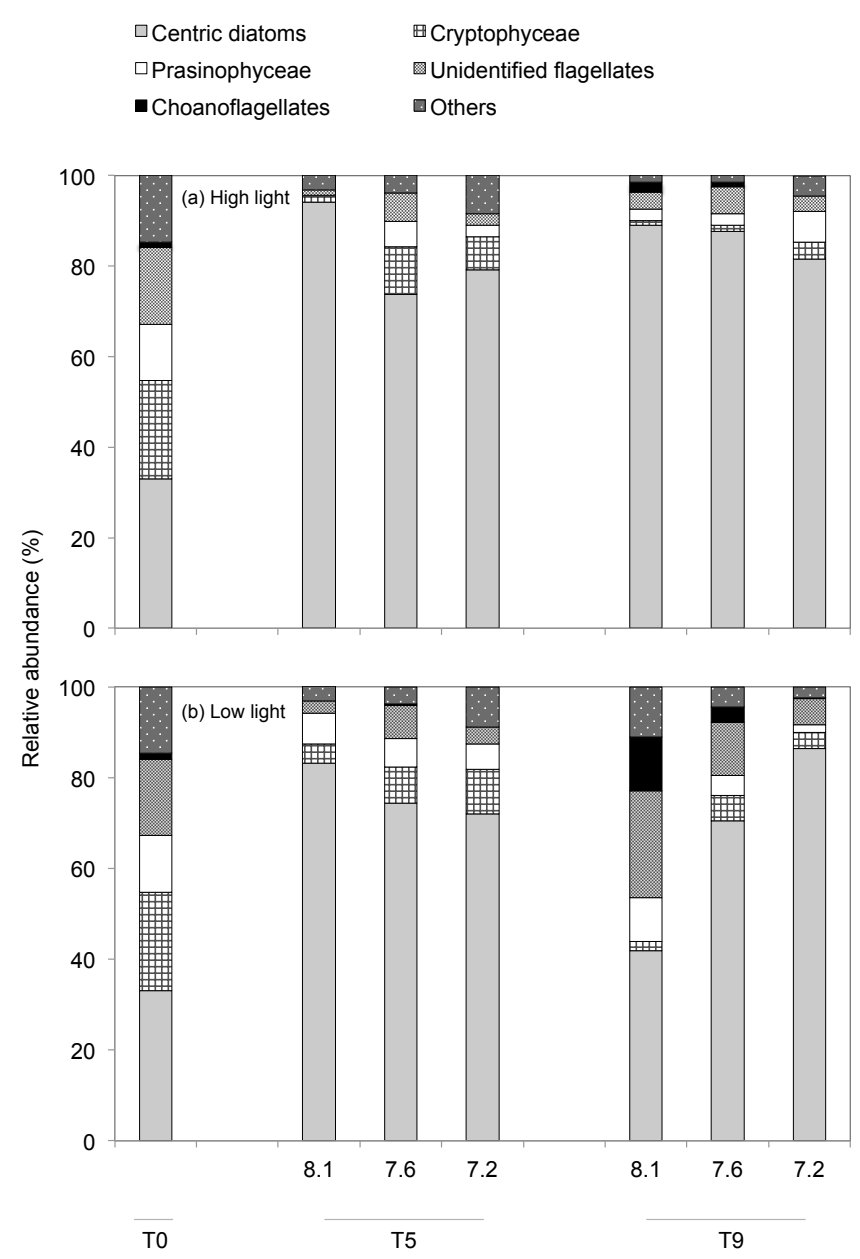

Figure 6. Relative abundance of six groups of protists at the beginning (T0), the middle (T5) and the end (T9) of the microcosm experiment for (a) high light (HL) and (b) low light (LL) treatments. The group "Others" includes pennate diatoms, Dinophyceae, Chrysophyceae, Dictyophyceae, Euglenophyceae, ciliates and unidentified cells. Each bar plot represents a $\mathrm{pH}$ treatment. The bar plot at T0 represents the initial community assemblage before $\mathrm{pH}$ manipulations, and is therefore the same for both light treatments.

\subsection{Bacteria}

Bacterial abundances under both light treatments showed a moderate increase during the experiment (Fig. 4g, h). Although it is not evident in Fig. $4 \mathrm{~g}$, h, the bacterial abundances were significantly different between both light and $\mathrm{pH}$ treatments, in contrast with the other variables presented above (Table 3). As shown in Fig. 5d, the mean bacterial abundance decreased with increasing proton concentrations under HL but showed no proton- or pH-related effect under LL (Table 4).
Table 5. $F_{\mathrm{V}} / F_{\mathrm{m}}$ ratios for three different $\mathrm{pH}_{\mathrm{T}}$ measured on days T2, T4, T6, T7, and T9 under high light (HL) and low light (LL) conditions.

\begin{tabular}{lrrr|rr|rr|rr}
\hline & $\mathrm{pH}$ & \multicolumn{2}{c|}{8.1} & \multicolumn{2}{|c|}{7.8} & \multicolumn{2}{|c}{7.2} \\
\cline { 2 - 8 } & & $\mathrm{HL}$ & LL & HL & LL & HL & LL \\
\hline Time & T2 & 0.52 & 0.55 & 0.51 & 0.53 & 0.44 & 0.46 \\
(day) & T4 & 0.59 & 0.58 & 0.58 & 0.59 & 0.5 & 0.5 \\
& T6 & 0.49 & 0.47 & 0.44 & 0.51 & 0.5 & 0.5 \\
& T7 & 0.4 & 0.4 & 0.41 & 0.42 & 0.5 & 0.52 \\
& T9 & 0.31 & 0.32 & 0.33 & 0.36 & 0.36 & 0.37 \\
\hline
\end{tabular}

\subsection{DMSP and DMS concentrations}

The $\mathrm{DMSP}_{\mathrm{T}}$ concentrations showed the same general temporal pattern in all microcosms (Fig. 7a, b). Initial average DMSP $_{\mathrm{T}}$ concentration was $7 \pm 3 \mathrm{nmol} \mathrm{L}^{-1}$, and remained at this low level during the first 5 days of the experiment, increased sharply between $\mathrm{T} 5$ and $\mathrm{T} 6$ to reach values of $80 \mathrm{nmol} \mathrm{L}^{-1}$ (under HL) and $120 \mathrm{nmol} \mathrm{L}^{-1}$ (under LL), and remained high but variable for the rest of the experiment. Of the two stressors tested, only the $\mathrm{pH}$ gradient significantly influenced the $\mathrm{DMSP}_{\mathrm{T}}$ concentrations (Table 3). As shown in Fig. 8a, the mean DMSP $_{\mathrm{T}}$ concentration decreased with increasing proton concentration, but only under the HL treatment between $\mathrm{pH}_{\mathrm{T}} 8.1$ and 7.6 (Table 4).

The DMSP ${ }_{d}$ concentrations started at $0.5-1.8 \mathrm{nmol} \mathrm{L}^{-1}$, decreased slightly until $\mathrm{T} 5$ and then tended to increase, again slightly, to reach maximum values between 2 and $3 \mathrm{nmol} \mathrm{L}^{-1}$ near the end of the experiment (Fig. 7c, d). Neither the light nor the $\mathrm{pH}_{\mathrm{T}}$ treatments significantly affected the $\mathrm{DMSP}_{\mathrm{d}}$ concentrations over the period of incubation (Table 3).

In most of the microcosms, temporal changes in DMS concentrations were very similar to those in $\mathrm{DMSP}_{\mathrm{T}}$ and were characterised by a gradual increase from 0.54 to ca. $4 \mathrm{nmol} \mathrm{L}^{-1}$ between $\mathrm{T} 1$ and T5 and a sudden increase to $10-20 \mathrm{nmol} \mathrm{L}^{-1}$ between $\mathrm{T} 5$ and T7, followed by either a plateau or a decrease in concentrations until the end of the experiment (Fig. 7e, f). The sharp increase in DMS was not observed at the two lowest levels of $\mathrm{pH}_{\mathrm{T}}$ (i.e. 7.4 and 7.2). At these low $\mathrm{pH}_{\mathrm{T}}$ values, DMS concentrations did not exceed $6 \mathrm{nmol} \mathrm{L}^{-1}$ during the phytoplankton growth phase. Of the two stressors tested, only the $\mathrm{pH}$ gradient had a significant effect on the DMS concentrations over time (Table 3). As shown in Fig. 8b, the mean DMS concentration decreased with increasing proton concentration (Table 4). The average DMS : DMSP $_{d}$ ratio followed the same trend as for DMS concentrations, showing a linear decrease over the whole range of proton concentration, irrespective of the light treatment (Fig. 8c, Table 4). 

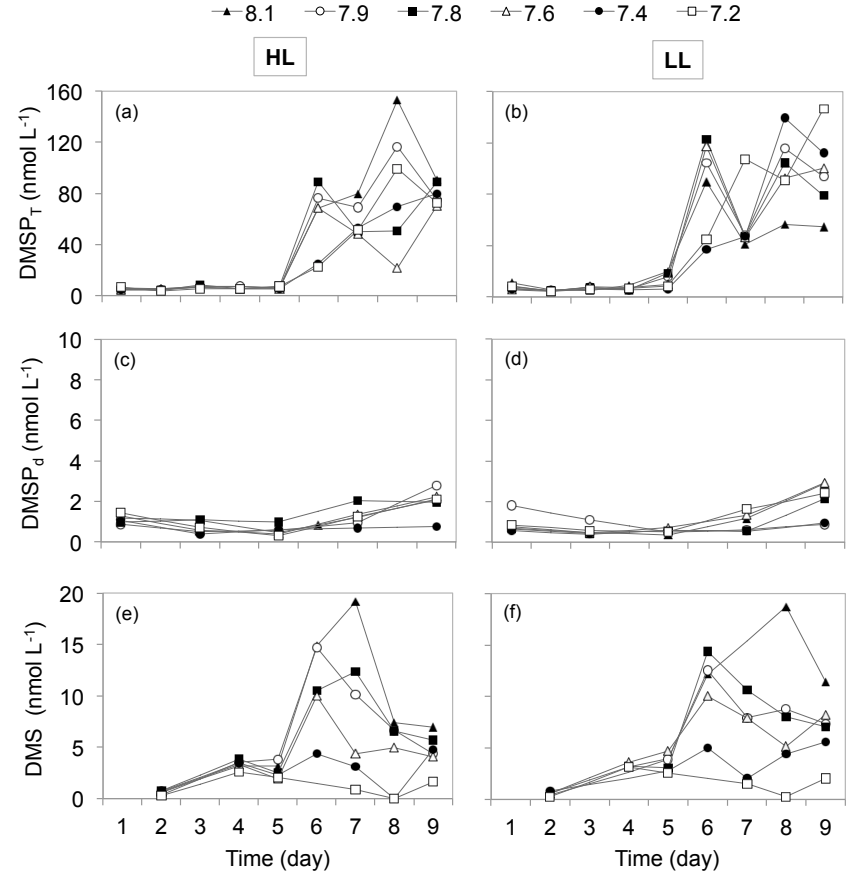

Figure 7. Temporal variations in (a, b) total DMSP $\left(\mathrm{DMSP}_{\mathrm{T}}\right)$, (c, d) dissolved DMSP $\left(\right.$ DMSP $\left._{d}\right)$, and $(\mathbf{e}, \mathbf{f})$ DMS concentrations during the microcosm experiment. Left and right panels show variations under the high light (HL) and low light (LL) treatments, respectively. Each curve represents a microcosm identified by its mean $\mathrm{pH}_{\mathrm{T}}$ value.

\section{Discussion}

In this study, a natural Arctic plankton community in a prebloom stage (initial high nutrient-low $\mathrm{Chl} a$ concentrations) was exposed over 9 days to reduced $\mathrm{pH}$ conditions under two contrasting light regimes. The two light regimes were designed to simulate the mean irradiance in an ice-free $5 \mathrm{~m}$ thick surface mixed layer (HL, marginal ice bloom conditions) and the mean irradiance at $5 \mathrm{~m}$ depth under a melting ponded ice pack (LL, under-ice bloom and/or subsurface chlorophyll maximum conditions). The $\mathrm{pH}_{\mathrm{T}}$ gradient comprised 6 levels covering the range of $\mathrm{pH}$ expected between the present and the year 2300 . We recognize that the rapid change in $\mathrm{pH}$ to which the plankton assemblage was exposed at the beginning of our study is not representative of the more gradual acidification that is taking place in the ocean. For this reason, negative impacts should be interpreted as potential extreme responses, and the planktonic community could be more adaptable than is implied by our results.

\subsection{General bloom characteristics and associated variations in DMSP and DMS}

During this experiment, a phytoplankton bloom numerically dominated by the centric diatom Chaetoceros spp. and by photosynthetic pico-eukaryotes occurred almost simultane-
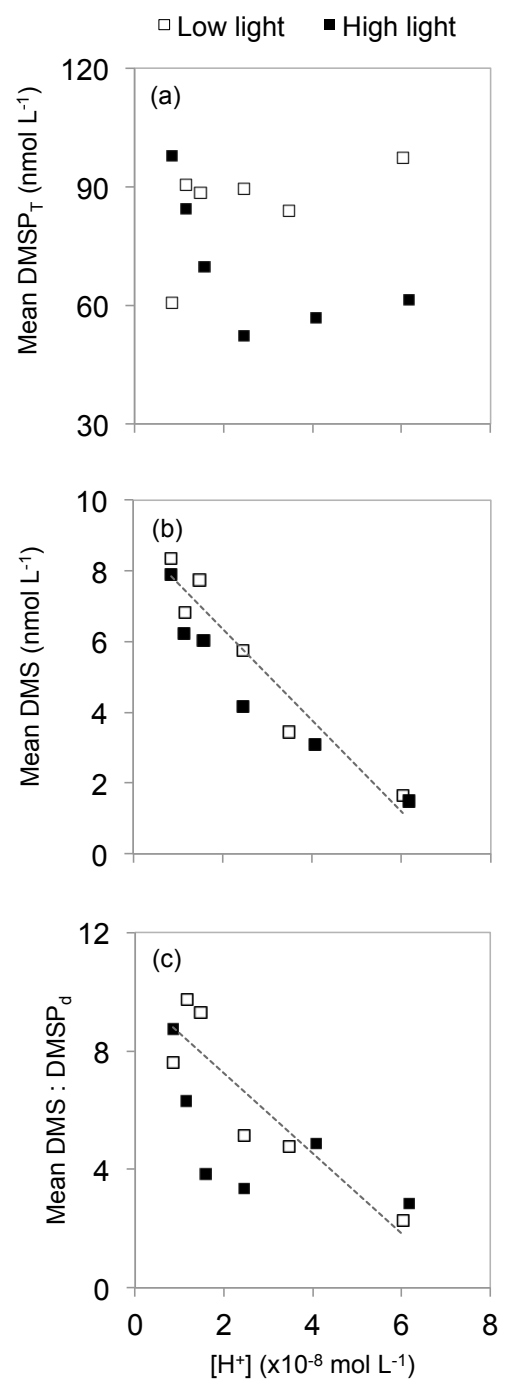

Figure 8. Relationships between the mean proton concentration values $\left(\left[\mathrm{H}^{+}\right]\right)$and (a) mean total DMSP concentration, (b) mean DMS concentration, and (c) mean DMS : $\mathrm{DMSP}_{\mathrm{d}}$ ratio. Values are the mean over the duration of the incubation in each microcosm. Significant regressions are shown as dashed lines, details of which are given in Table 4.

ously in all microcosms (Fig. 4c-f). The exponential growth phase lasted 6-7 days, a period during which the concentration of all three monitored nutrients decreased, with $\mathrm{NO}_{3}^{-}$ reaching near-zero values. The $F_{\mathrm{v}} / F_{\mathrm{m}}$ ratios around 0.5 characterised the period of exponential growth in all microcosms, including the controls (Table 5). The peak of the bloom and $\mathrm{NO}_{3}^{-}$depletion were followed by a decrease of $F_{\mathrm{v}} / F_{\mathrm{m}}$ ratios and a stabilisation or slight decrease in phytoplankton abundances (Figs. 3 and $4 \mathrm{c}-\mathrm{f}$ ). As the initial concentrations of nutrients in the incubation bags were similar to the concentrations found in the upper mixed layer before the spring bloom in Baffin Bay, we are confident that the bloom that took place in our bags is comparable to the spring bloom 
naturally developing in these waters (Tremblay et al., 2002, 2006). Furthermore, the dominance of diatoms during our experiment was expected as blooms of this phytoplankton group are commonly found at the marginal ice zone in the Arctic, and in Baffin Bay in particular (Poulin et al., 2011), and tend to dominate spring primary production when nutrients are non-limiting in this region (Heimdal, 1989; Matrai and Vernet, 1997; Wolfe et al., 1999; Von Quillfeldt, 2000).

Pico-phytoplankton were numerically more abundant than nano-phytoplankton during our experiment, representing between $54 \%$ (during the diatom bloom) and up to $96 \%$ (post bloom period) of total phytoplankton abundance. High picophytoplankton abundances (64\% of total photosynthetic cell abundance $\leq 20 \mu \mathrm{m}$ ) have been reported by Tremblay et al. (2009) in the Canadian Arctic where, due to their small size, they accounted for only $16 \%$ of total Chl $a$. During the growth phase of this study, concentrations of Chl $a$ displayed a stronger correlation with nano-phytoplankton abundances $\left(r^{2}=0.78, p<0.001\right)$ than they did with pico-phytoplankton $\left(r^{2}=0.48, p<0.001\right)$, despite the latter's numerical dominance. The taxonomy of the pico-phytoplankton was not determined during our study, but Micromonas-like species are known to be a major component of the photosynthetic picoeukaryotes in the Arctic (Lovejoy et al., 2007; Tremblay et al., 2009).

The $\mathrm{DMSP}_{\mathrm{T}}$ concentrations measured during the development of the diatom bloom correspond to a $\mathrm{DMSP}_{\mathrm{T}}$ : Chl $a$

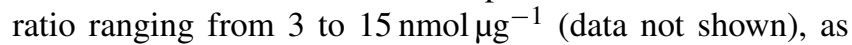
expected for this phytoplankton group (Stefels et al., 2007). The sharp increase in $\mathrm{DMSP}_{\mathrm{T}}$, measured between $\mathrm{T} 5$ and T6 under both light regimes and at all $\mathrm{pH}_{\mathrm{T}}$ values investigated, was, however, unexpected (Fig. 7a, b), as it contrasts with results from previous mesocosm experiments that showed a more gradual increase in DMSP along with algal biomass (Vogt et al., 2008; Archer et al., 2013; Park et al., 2014). During our experiment, this sharp increase in $\mathrm{DMSP}_{\mathrm{T}}$ and DMS coincided with the exhaustion of $\mathrm{NO}_{3}^{-}$, with the exception of the microcosms at $\mathrm{pH}_{\mathrm{T}} 7.4$ and 7.2 under both light regimes (Fig. 3a, b). At the two latter $\mathrm{pH}$ levels, the increase of $\mathrm{DMSP}_{\mathrm{T}}$ between T5 and T6 was of lower magnitude compared to the other microcosms, and the remaining $\mathrm{NO}_{3}^{-}$concentrations varied from 0.9 to $2.6 \mu \mathrm{mol} \mathrm{L}^{-1}$ in these bags at T6 (Fig. 7a, b). Previous laboratory experiments have shown that $\mathrm{NO}_{3}^{-}$limitation could induce a 25 -fold increase in diatom $\mathrm{DMSP}_{\mathrm{T}}$ cellular quotas (Keller et al., 1999; Bucciarelli and Sunda, 2003; Sunda et al., 2007). Our results show a ca. 9-fold increase of $\mathrm{DMSP}_{\mathrm{T}}$ between T5 and T6, which corresponds well with the values found in the literature (Sunda et al., 2007). Unicellular algae are known to synthesise DMSP during episodes of stress or senescence as an overflow mechanism to evacuate excess energy, sulfur, and carbon, while allowing the cell to function (Stefels, 2000; Hopkins and Archer, 2014). In response to $\mathrm{NO}_{3}^{-}$limitation, diatoms could have switched from the synthesis of glycine betaine (GBT), a nitrogen-containing osmolyte, to its sul- fur analog DMSP (Andrea, 1986; Keller et al., 1999). Altogether, these results suggest a relationship between the intensity of nitrate depletion and the magnitude of DMSP synthesis by the diatom community during our experiment. These results also suggest that diatoms could have more difficulty in efficiently taking up and/or assimilating $\mathrm{NO}_{3}^{-}$at lower $\mathrm{pH}$.

\subsection{Phytoplankton community and nutrient uptake response to the $\mathrm{pH}$ gradient}

Lowering the $\mathrm{pH}$ had a negative impact on the mean concentration of Chl $a$, as well as on the mean abundance of nano-phytoplankton during the 9-day experiment (Fig. 5a, b, Table 4). Considering that Chaetoceros diatoms accounted for more than $65 \%$ of the total abundance of the large phytoplankton (>2 $\mu \mathrm{m})$ and most of the Chl $a$ build-up, these results suggest that net carbon fixation by diatoms was negatively impacted by the decrease in $\mathrm{pH}$, as observed in other studies (Gao and Campbell, 2014, and references therein). Altered seawater carbonate chemistry could perturb the energy requirements of diatom cells, leading to changes in respiration, cell surface, and intracellular $\mathrm{pH}$ stability (Gao and Campbell, 2014 and reference therein). Such energy reallocation could force diatoms to assign more energy to repair mechanisms and ion transport to remedy the acid-base perturbation, thus impairing their growth.

The relative uptake of nutrients was also impacted by the $\mathrm{pH}_{\mathrm{T}}$ treatments in diatoms. The observed linear decrease of the $\mathrm{Si}(\mathrm{OH})_{4}: \mathrm{NO}_{3}^{-}$concentration ratio with increasing proton concentration, which was mostly driven by a reduction in $\mathrm{Si}(\mathrm{OH})_{4}$ consumption, either suggests that, at low $\mathrm{pH}_{\mathrm{T}}$, diatom cells were less silicified or that non-diatom phytoplankton made a larger contribution to nutrient drawdown. The former is the most likely explanation since diatom abundance increased in all experimental treatments and numerically dominated the cell community $>2 \mu \mathrm{m}$ at $\mathrm{T} 5$ and $\mathrm{T} 9$, irrespective of the $\mathrm{pH}_{\mathrm{T}}$ level tested. This explanation is also consistent with laboratory studies that previously reported an impairment of $\mathrm{Si}(\mathrm{OH})_{4}$ uptake in diatom cultures grown at low pH (Milligan et al., 2004; Hervé et al., 2012; Mejía et al., 2013). In Hervé et al. (2012), the cells exhibited similar growth rates at high and low $\mathrm{pH}$, implying that the negative impact of a low $\mathrm{pH}$ on silification does not preclude bloom development in nature.

The pico-phytoplankton were also impacted by the decrease in $\mathrm{pH}_{\mathrm{T}}$ (i.e. the augmentation of proton concentration), albeit differently from the nano-phytoplankton. As shown in Fig. 5c, their mean abundance increased as the proton concentration increased from 0.1 to $2.0 \times 10^{-8} \mathrm{~mol} \mathrm{~L}^{-1}$ and then tends to stabilise at $\mathrm{pH}_{\mathrm{T}}$ below 7.6 (see Table 1 for the corresponding proton concentration). In contrast to our study, Richier et al. (2014) reported a negative impact of ocean acidification not only on nano-phytoplankton but on pico-phytoplankton as well during a microcosm experiment using a similar methodology. In this study conducted 
with water from the north-west European shelf, lowering the $\mathrm{pH}$ resulted in a decrease in the abundance (cell number) and biomass $(\mathrm{Chl} a$ ) of phytoplankton $<10 \mu \mathrm{m}$. These contrasting results could reflect differences in the initial picophytoplankton community composition and possible speciesspecific physiological response to OA. By contrast, a positive influence of a decreasing $\mathrm{pH}_{\mathrm{T}}$ on pico-phytoplankton abundance, and particularly Micromonas-like phylotypes, has been previously reported by Hama et al. (2016) for a coastal planktonic community near Japan, as well as by others based on mesocosm experiments (Paulino et al., 2008; Brussaard et al., 2013). This response could be explained by an adjustment of the CCM (carbon concentrating mechanism) used by these small cells at low $\mathrm{pH}$. Indeed, pico-phytoplankton may rely more on $\mathrm{CO}_{2}$ diffusion at lower $\mathrm{pH}$ than on investing energy in active $\mathrm{CO}_{2}$ and $\mathrm{HCO}_{3}^{-}$uptake (Brussaard et al., 2013). The energy saved that way could translate into higher growth. Moreover, small pico-phytoplankton species are known to possess less effective CCM than diatoms (Mackey et al., 2015). If the pico-phytoplankton thriving in our experiment were not saturated with $\mathrm{CO}_{2}$ at in situ levels, an increase in $p \mathrm{CO}_{2}$ could have stimulated photosynthesis and growth of this size group (Brussaard et al., 2013).

In summary, during our experiment, OA stimulated picophytoplankton net growth over the whole range of $\mathrm{pH}_{\mathrm{T}}$ investigated while impairing the development of nanophytoplankton, especially at the lowest $\mathrm{pH}_{\mathrm{T}}$ tested. This implies that OA will most probably maintain or increase the numerical dominance of pico-phytoplankton over the nanophytoplankton in the Arctic Ocean (Newbold et al., 2012; Davidson et al., 2016). Tremblay et al. (2012) suggested that climate warming and the associated increase in surface water stratification could also favour the growth of small cells relative to larger diatoms, thus favouring the diminution of primary-producer biomass. Our results suggest that OA could accentuate this community response caused by warming and stratification.

\subsection{Effect of the $\mathrm{pH}$ gradient on dimethylated compounds}

During our experiment, $\mathrm{DMSP}_{\mathrm{T}}$ and DMS responded differently to decreasing $\mathrm{pH}_{\mathrm{T}}$. While $\mathrm{DMSP}_{\mathrm{T}}$ concentrations decreased between $\mathrm{pH}_{\mathrm{T}}$ of 8.1 and 7.6 (see Table 1 for corresponding proton concentration values) only under $\mathrm{HL}$ conditions, DMS concentrations decreased linearly over the full range of $\mathrm{pH}_{\mathrm{T}}$ investigated and under both light regimes (Fig. 8, Table 4).

Although not linear over the full range of $\mathrm{pH}_{\mathrm{T}}$ investigated, the decrease in $\mathrm{DMSP}_{\mathrm{T}}$ concentrations measured under HL conditions was, nevertheless, important (50\%) over the range of $\mathrm{pH}_{\mathrm{T}}$ predicted for ocean surface waters by 2100 (8.1 to 7.6, approximately corresponding to proton concentration between 0.1 and $3.0 \times 10^{-8} \mathrm{~mol} \mathrm{~L}^{-1}$ in Fig. 8a). The mean abundance of nano-phytoplankton varied little within this $\mathrm{pH}_{\mathrm{T}}$ range, while the abundance of pico-phytoplankton increased (Fig. 5b, c). The pH-induced decrease in DMSP $_{\mathrm{T}}$ under HL conditions could thus be related to a decrease in algal cellular DMSP quota. The more ambiguous response of $\mathrm{DMSP}_{\mathrm{T}}$ to the $\mathrm{pH}_{\mathrm{T}}$ decrease, compared to DMS, is in line with previous experiments that have also observed similar responses to OA for those two sulfur compounds (Vogt et al., 2008; Hopkins et al., 2010; Archer et al., 2013; Hopkins and Archer, 2014; Webb et al., 2015). Together, these results suggest that ongoing OA will have a stronger impact on the algal and bacterial DMSP transformation into DMS than on the synthesis of DMSP by algae (Vogt et al., 2008; Hopkins et al., 2010; Webb et al., 2016).

As in this study, several OA experiments conducted in mesocosms or with monospecific phytoplankton cultures have revealed a consistent decrease in DMS concentration under the influence of decreasing pH (Avgoustidi et al., 2012; Arnold et al., 2013; see Table 6 for a summary of past mesocosm and microcosm experiments). The percentage decreases observed during our microcosm experiment over the full range of $\mathrm{pH}_{\mathrm{T}}$ investigated are consistent with the results from other studies that also found decreases ranging from -34 to $-82 \%$ (Table 6). Keeping in mind the limitations of the experimental protocols, the consistency of the DMS response to $\mathrm{pH}$ at different latitudes and with different planktonic assemblages suggests that the potential for DMS net production during the seasonal bloom is likely to decrease in the Arctic during the next few centuries. However, it is important to also keep in mind that our short-term experiment precludes any acclimation of the algae to their new environment, something that is likely to take place in response to a more gradual change in $\mathrm{pH}$. In that regard, two studies have highlighted the acclimation capacity or evolutionary adaptation of the strong DMS(P) producer Emiliana huxleyi to decreases in $\mathrm{pH}$ (Lohbeck et al., 2012, 2014). More studies are needed to fully assess how the acclimation capacity of phytoplankton will combine with short-term physiological responses to environmental stressors to shape future DMS emissions and climate.

Multiple interrelated processes interact in the global ocean to regulate DMS dynamics. Hence, several hypotheses have been proposed to explain the observed attenuation of DMS concentrations at low $\mathrm{pH}$. Whereas some authors suggest a physiological response of phytoplankton under conditions of acidification (Avgoustidi et al., 2012; Hopkins and Archer, 2014), others propose a $\mathrm{pH}$-induced impact on bacterial activity (Archer et al., 2013; Webb et al., 2015) or on zooplankton grazing (Kim et al., 2010; Park et al., 2014). In our study, the absence of DMSP and DMS gross rate measurements limits our interpretation of the observed decreasing DMS trend. Results from the few previous studies where gross rate measurements were performed do not show a consistent effect of a decrease in $\mathrm{pH}$ on neither DMSP synthesis nor DMS consumption (Archer et al., 2013; Hopkins and Archer 2014). Despite the unavailability of rate measure- 
Table 6. Changes in dimethyl sulfide (DMS) concentrations reported in previous $\mathrm{CO}_{2}$ perturbation experiments in mesocosms or microcosms $\Delta \mathrm{pH}$ represents the change in $\mathrm{pH}_{\mathrm{T}}$ applied in each experiment. In our study, $\mathrm{pH}_{\mathrm{T}}$ ranged from 7.94 to 7.16 at day $\mathrm{T} 1$. ND: no data. The experiment was carried out in the coastal waters of Korea (Jangmok, $34.6^{\circ} \mathrm{N}$ and $128.5^{\circ} \mathrm{E}$ )

\begin{tabular}{lrrrl}
\hline Location & $\Delta \mathrm{pH}$ & $\begin{array}{r}p \mathrm{CO}_{2} \text { range } \\
(\mu \mathrm{atm})\end{array}$ & $\begin{array}{r}\text { Change in } \\
\text { DMS }(\%)\end{array}$ & Reference \\
\hline Baffin Bay, Arctic & -0.75 & $500-3000$ & -80 & This study \\
Baltic Sea & -0.4 & $350-1500$ & -34 & Webb et al. (2016) \\
Raunefjorden, Norway & -0.6 & $280-3000$ & -60 & Webb et al. (2015) \\
Jangmok, Korea & -0.5 & $160-830$ & -82 & Park et al. (2014) \\
Kongsfjorden, Svalbard & -0.8 & $180-1420$ & -60 & Archer et al. (2013) \\
Raunefjorden, Norway & -0.2 & $300-750$ & -40 & Avgoustidi et al. (2012) \\
Raunefjorden, Norway & -0.3 & $300-750$ & -57 & Hopkins et al. (2010) \\
\hline Raunefjorden, Norway & -0.5 & $300-750$ & 0 & Vogt et al. (2008) \\
\hline NW European Shelf & -0.4 & $340-1000$ & 225 & Hopkins and Archer (2014) \\
Jangmok, Korea & ND & $400-900$ & 80 & Kim et al. (2010) \\
\hline
\end{tabular}

ments in our study, the dominance of diatoms, an algal group lacking DMSP lyase enzymes, suggests that bacteria may have played a critical role in the observed DMS dynamics. Low $\mathrm{pH}$ conditions have been reported to stimulate the productivity, and hence the carbon demand, of bacteria (Maas et al., 2013; Piontek et al., 2013; Endres et al., 2014). This increase in bacterial productivity could in turn have resulted in an increase in sulfur demand, leading to a decrease in bacterial DMS yield (percentage of the DMSP taken up by the bacteria and cleaved into DMS). This interpretation is supported by the linear decrease in the DMS : $\mathrm{DMSP}_{\mathrm{d}}$ ratio observed over the full range of $\mathrm{pH}_{\mathrm{T}}$ investigated (Fig. 8c, Table 4), which suggests that, at lower $\mathrm{pH}$, bacteria increasingly favoured the demethylation over the cleavage pathways of DMSP degradation. Although the decrease of this ratio could also result from an increase in microzooplankton grazing on diatoms (Jones et al., 1998), we found no significant relationship between the micrograzers and phytoplankton, $\mathrm{pH}$, or DMS. Archer et al. (2013) also proposed that the pHinduced decrease in DMS observed during their experiments could partly be explained by a decrease in bacterial DMS yield related to the increase in phytoplankton biomass and net primary production at lower $\mathrm{pH}$, as well as the associated increase in bacterial protein production and sulfur demand. In contrast with their observations, however, phytoplankton biomass did not increase but decreased with $\mathrm{pH}_{\mathrm{T}}$ during our study. Nevertheless, this does not preclude the possibility of an increase in dissolved organic carbon (DOC) release by phytoplankton at low $\mathrm{pH}$, as previously reported (Riebesell et al., 2013). Whether the productivity and sulfur demand of DMS-consuming bacteria are also stimulated at low $\mathrm{pH}$ is unknown. If so, they may also have contributed to the $\mathrm{pH}$ induced decrease in DMS reported here and in other studies.

Finally, it is unlikely that grazing played a major role in the $\mathrm{pH}$-associated reduction in DMS concentrations we observed. Although removing large grazers before the incuba- tion may have affected the relative importance of microzooplankton grazing on phytoplankton during our experiment, no relationships between protist abundance and $\mathrm{H}^{+}$or DMS were found. Modifications in micro-grazing activity at low pH have been reported to either stimulate (Kim et al., 2010) or decrease net DMS production (Park et al., 2014). Park et al. (2014) attributed the reduction in grazing to a $\mathrm{pH}$-induced shift in the phytoplankton species composition, with larger diatoms outcompeting smaller DMSP-rich dinoflagellates in acidified treatments, resulting in a weaker grazing pressure on the small DMSP-rich phytoplankton species and therefore less release of DMSP and DMS. In our study, small DMSPrich producers were not abundant and diatoms dominated the community biomass over the full range of $\mathrm{pH}_{\mathrm{T}}$ investigated. It is important to note that Dinophyceae did not survive in our incubation bags, so no conclusion can be drawn as to how they could have responded to a decrease in $\mathrm{pH}$ and influenced DMS net production.

\subsection{Response to the contrasting light regimes}

The two experimental light treatments applied in this study had no significant effects on the temporal evolution, magnitude and taxonomic composition of the phytoplankton bloom (Table 3). These results show that both nano-phytoplankton and pico-phytoplankton achieved optimal growth in the range of PAR used in our treatments. During a laboratory experiment, Gilstad and Sakshaug (1990) found that 10 Arctic diatom species exhibited negligible variations in growth rate at PAR levels ranging from 50 to $500 \mu \mathrm{mol}$ quanta $\mathrm{m}^{-2} \mathrm{~s}^{-1}$, while their growth rate increased linearly with increased PAR from 0 to $50 \mu \mathrm{mol}$ quanta $\mathrm{m}^{-2} \mathrm{~s}^{-1}$. During our experiment, PAR ranged from 61 to $402 \mu$ mol quanta $\mathrm{m}^{-2} \mathrm{~s}^{-1}$ (Table 2), and these values fall within the tolerance range reported by Gilstad and Sakshaug (1990). Moreover, the phytoplankton community in our incubation was initially 
taken at $38 \mathrm{~m}$ depth where PAR irradiance was as low as $7 \mu \mathrm{mol}$ quanta $\mathrm{m}^{-2} \mathrm{~s}^{-1}$. Thus, diatoms in our experience were already very well adapted for growing at very low light levels. As they were then capable of growing as efficiently in both the HL and LL treatment, we could assess that diatoms during our experiment were capable of adapting themselves to higher irradiances very quickly. This is supported by the high and similar $F_{\mathrm{v}} / F_{\mathrm{m}}$ ratios recorded during the growth phase in both light treatments (Table 5), suggesting that photosynthesis was equally efficient at HL and LL exposure. These results suggest that phytoplankton exiting the ice pack would not necessarily experience a light shock as severe as previously noted by others (Vance et al., 2013; Galindo et al., 2016).

Among the biological variables measured, only bacteria showed a significant response to the different light treatments, with higher abundances at LL than at HL exposure (Table 3, Fig. 5d). This may reflect the known sensitivity of bacteria to UVB radiation (Herndl et al., 1993), which was absent in our LL treatment.

We found no difference in the DMSP and DMS concentrations between the two light regimes tested, as the $\mathrm{DMSP}_{\mathrm{T}}$ and DMS variations were very similar under both LL and HL conditions (Table 3). This result was unexpected considering that several processes associated with the DMS cycle are either directly (e.g. DMS photo-oxidation) or indirectly (e.g. DMS bacterial production under high ultraviolet radiation - UV-R) light-sensitive (Sunda et al., 2002; Slezak et al., 2007; Galí et al., 2011). Previous studies demonstrated a strong positive correlation between the solar radiation dose (SRD) received by the plankton community in the upper mixed layer and the DMS concentrations measured in surface waters (Toole and Siegel, 2004; Vallina and Simó, 2007). Hence, our working hypothesis was that light conditions under the ice pack (low PAR and quasi-absence of UV-R) would result in lower DMS concentrations than under open water light conditions (high PAR and high UV-R). The absence of such light response may suggest that our LL treatment, as it was already light-saturating for diatoms, was not different enough from our HL treatment to trigger a different photoinduced response of diatoms. Hence, the differences in PAR and UV radiation between a $5 \mathrm{~m}$ mixed layer depth in icefree water and under ponded first-year ice (or a subsurface chlorophyll layer) in summer may not be sufficient to significantly affect the net production of DMSP and DMS.

\section{Conclusion}

During this study, we demonstrated that a rapid decrease in surface water $\mathrm{pH}$ could negatively impact the net production of algal biomass as well as DMS concentrations in Baffin Bay waters. Irrespective of the treatment, a nanophytoplankton (mostly diatoms) and pico-phytoplankton bloom developed within 5 to 7 days in each of our micro- cosms. The growth of pico-phytoplankton was stimulated at low $\mathrm{pH}_{\mathrm{T}}$, whereas the diatoms, which dominated the algal community in term of biomass at all $\mathrm{pH}_{\mathrm{T}}$ levels investigated, had their abundance negatively affected by the acidification, especially at the lowest $\mathrm{pH}_{\mathrm{T}}$ level tested when compared to the controls. These results show that OA can potentially affect the magnitude of diatoms biomass in Arctic waters and enhance the already observed shift towards smaller autotrophic cells due to increased stratification ( $\mathrm{Li}$ et al., 2009; Tremblay et al., 2012), although our results do not account for the acclimation and/or evolutionary adaptation potential of natural microbial communities.

Concurrent with the response of phytoplankton to OA, the DMS dynamics were strongly affected by decreasing the $\mathrm{pH}_{\mathrm{T}}$, with a $80 \%$ reduction in average DMS concentrations between the control and the lowest $\mathrm{pH}_{\mathrm{T}}$ investigated (from $\mathrm{pH}_{\mathrm{T}} 8.1$ to 7.2). This result adds to conclusions found in $70 \%$ of published studies that have focused on pH-DMS dynamics and showed a decrease in DMS concentrations as $\mathrm{pH}$ decreases. In contrast, the $\mathrm{pH}$-induced decrease in $\mathrm{DMSP}_{\mathrm{T}}$ concentration was less pronounced, as it only decreased under the $\mathrm{HL}$ treatment at relatively high $\mathrm{pH}_{\mathrm{T}}$ (8.1 to 7.6). The synthesis of DMSP by unicellular algae appears to be less sensitive to OA than processes responsible for its conversion into DMS, as previously hypothesised by other authors (Vogt et al., 2008; Hopkins et al., 2010; Webb et al., 2016). The lack of rate measurements during our study precludes a definitive explanation for this trend, but a decrease in bacterial DMS yield seems to be the most probable candidate.

Our data highlighted a remarkable similarity in responses of the phytoplankton community and DMS-related processes to experimental variations in light (LL versus HL treatment). Indeed, neither the phytoplankton community nor the dimethylated sulfur compounds exhibited significantly different signatures between the two light treatments, which were designed to simulate contrasting light conditions, experienced by marginal ice blooms (ice-free surface mixed layer) versus under-ice blooms (irradiance under a melting pondered ice pack) or subsurface chlorophyll maxima. Although further studies are needed to fully assess the importance of light in the context of climate change in the Arctic, our results show that Arctic diatoms may bloom under light conditions much lower than the one tested here. This apparent capacity of Arctic diatoms to grow under extremely low light conditions should be explored in future studies. As short-term impacts of OA on the DMS cycle become clearer, future studies should focus on assessing the potential susceptibility and adaptive mechanisms of microbial DMS(P) producers, processes that likely develop on a timescale closer to the natural OA rate.

Data availability. Metadata are available on the Polar Data Catalog website at www.polardata.ca/pdcsearch/PDCSearchDOI.jsp? 
doi_id=12823. Data are available on request by contacting the first author.

Author contributions. R. Hussherr was responsible for the elaboration of the experimental design, the sampling process, the data analysis and processing, and the redaction of this paper. Several co-authors provided specific data included in the paper and all coauthors contributed to the final edition of the paper.

Competing interests. The authors declare that they have no conflict of interest.

Acknowledgements. The authors wish to thank commander Alain Gariépy, the officers, and crew of the Canadian ice-breaker NGCC Amundsen for their support during the project. We also want to thank Glenn Cooper and Kyle Simpson of the Institute of Ocean Sciences in Sidney, BC, Canada, for providing advice and the material and equipment needed for $\mathrm{pH}$ measurements, Isabelle Courchesne and Gabrièle Deslongchamps for the nutrients analysis, Marjolaine Blais for the flow cytometry analyses, and Jean-Bruno Nadalini for the taxonomic analyses. This study was funded by the NSERC Discovery Grant Program and Northern Research Supplement Program (M. Levasseur, M. Gosselin), as well as by the NETCARE network (funded under the NSERC Climate Change and Atmospheric Research program), ArcticNet (The Network of Centres of Excellence of Canada), and Fisheries and Oceans Canada. This is a contribution to the research programmes of NETCARE, ArcticNet, and Québec-Océan.

Edited by: L. Bopp

Reviewed by: two anonymous referees

\section{References}

ACIA: Arctic Climate Impact Assessment, Cambridge University Press, Cambridge, UK, 1042 pp., 2005.

Andrea, M. O.: The ocean as a source of atmospheric sulfur compounds, in: The Role of Sea-Air Exchange in Geochemical Cycling, edited by: Buat-Menard, P., Reidel, Dordrecht, the Netherlands, 331-362, doi:10.1007/978-94-009-4738-2_14, 1986.

Archer, S. D., Kimmance, S. A., Stephens, J. A., Hopkins, F. E., Bellerby, R. G. J., Schulz, K. G., Piontek, J., and Engel, A.: Contrasting responses of DMS and DMSP to ocean acidification in Arctic waters, Biogeosciences, 10, 1893-1908, doi:10.5194/bg10-1893-2013, 2013.

Arnold, H. E., Kerrison P., and Steinke, M.: Interacting effects of ocean acidification and warming on growth and DMS-production in the haptophyte coccolithophore Emiliania huxleyi, Glob. Change Biol., 19, 1007-1016, doi:10.1111/gcb.12105, 2013.

Asher, E. C., Dacey J. W. H., Jarniková, T., and Tortell, P. D.: Measurement of DMS, DMSO, and DMSP in natural waters by automated sequential chemical analysis, Limnol. Oceanogr.-Meth., 13, 451-462, doi:10.1002/lom3.10039, 2015.

Avgoustidi, V., Nightingale, P. D., Joint, I., Steinke, M., Turner, S. M., Hopkins, F. E., and Liss, P. S.: Decreased marine dimethyl sulfide production under elevated $\mathrm{CO}_{2}$ levels in mesocosm and in vitro studies, Environ. Chem., 9, 399-404, doi:10.1071/EN11125, 2012.

Belzile, C., Johannessen, S. C., Gosselin, M., Demers, S., and Miller, W. L.: Ultraviolet attenuation by dissolved and particulate constituents of first-year ice during late spring in an Arctic polynya, Limnol. Oceanogr., 45, 1265-1273, doi:10.4319/lo.2000.45.6.1265, 2000.

Brussaard, C. P. D., Noordeloos, A. A. M., Witte, H., Collenteur, M. C. J., Schulz, K., Ludwig, A., and Riebesell, U.: Arctic microbial community dynamics influenced by elevated $\mathrm{CO}_{2}$ levels, Biogeosciences, 10, 719-731, doi:10.5194/bg-10-719-2013, 2013.

Bucciarelli, E. and Sunda, W. G.: Influence of $\mathrm{CO}_{2}$, nitrate, phosphate, and silicate limitation on intracellular dimethylsulfoniopropionate in batch cultures of the coastal diatom Thalassiosira pseudonana, Limnol. Oceanogr., 48, 2256-2265, doi:10.4319/lo.2003.48.6.2256, 2003.

Caldeira, K. and Wickett, M. E.: Anthropogenic carbon and ocean pH, Nature, 425, p. 365, doi:10.1038/425365a, 2003.

Clayton, T. D. and Byrne, R. H.: Spectrophotometric seawater $\mathrm{pH}$ measurements: total hydrogen ion concentration scale calibration of m-cresol purple and at-sea results, Deep-Sea Res. Pt. I, 40, 2115-2129, doi:10.1016/0967-0637(93)90048-8, 1993.

Cohen, J., Screen, J. A., Furtado, J. C., Barlow, M., Whittleston, D., Coumou, D., Francis, J., Dethloff, K., Entkhabi, D., Overland, J., and Jones, J.: Recent Arctic amplification and extreme mid-latitude weather, Nat. Geosci., 7, 627-637, doi:10.1038/NGEO2234, 2014.

Cottingham, K. L., Lennon, J. T., and Brown, B. L.: Knowing when to draw the line: designing more informative ecological experiments, Front. Ecol. Environ., 3, 145-152, doi:10.1890/15409295(2005)003[0145:KWTDTL]2.0.CO;2, 2005.

Davidson, A. T., McKinlay, J., Westwood, K., Thomson, P. G., van den Enden, R., de Salas, M., Wright, S., Johnson, R., and Berry, K.: Enhanced $\mathrm{CO}_{2}$ concentrations change the structure of Antarctic marine microbial communities, Marine Ecol.-Prog. Ser., 552, 93-113, doi:10.3354/meps11742, 2016.

Demers, S., Belzile, C., Lean, D. R. S., Mostajir, B., Roy, S., de Mora, S., Bird, D., Gosselin, M., Chanut, J.-P., and Levasseur, M.: An experimental tool to study the effects of ultraviolet radiation on planktonic communities: a mesocosm approach, Environ. Tech., 19, 667-682, doi:10.1080/09593331908616723, 1998.

Dickson, A. G.: Standard potential of the reaction: $\mathrm{AgCl}(\mathrm{s})+\mathrm{H}_{2}(\mathrm{~g})=\mathrm{Ag}(\mathrm{s})+\mathrm{HCl}(\mathrm{aq})$, and the standard acidity constant of the ion $\mathrm{HSO}_{4}^{-}$in synthetic sea water from 273.15 to $318.15 \mathrm{~K}$, J. Chem. Thermodyn., 22, 113-127, doi:10.1016/0021-9614(90)90074-z, 1990.

Dickson, A. G., Sabine, C. L., and Christian, J. R. (Eds.): Guide to best practices for ocean $\mathrm{CO}_{2}$ measurements, PICES Special publication, 3, 191 pp., North Pacific Marine Science Organization, Sidney, Canada, 2007.

Dickson, D. M. G., Wyn Jones, R. G., and Davenport, J.: Steady state osmotic adaptation in Ulva lactuca, Planta, 150, 158-165, doi:10.1007/BF00582360, 1980.

Doney, S. C., Balch, W. M., Fabry, V. J., and Feely, R. A.: Ocean acidification, a critical emerging problem for the ocean sciences, Oceanography, 22, 16-25, doi:10.5670/oceanog.2009.93, 2009. 
Endres, S., Galgani, L., Riebesell, U., Schulz, K.-G., and Engel, A.: Stimulated bacterial growth under elevated $p \mathrm{CO}_{2}$ : results from an off-shore mesocosm study, PLoS ONE, 9, e99228, doi:10.1371/journal.pone.0099228, 2014.

Fabry, V. J., Macclintock, J. B., Mathis, J. T., and Grebmeier, J. M.: Ocean acidification at high latitudes: the bellwether, Oceanography, 22, 160-171, doi:10.5670/oceanog.2009.105, 2009.

Feely, R. A., Doney, S. C., and Cooley, S. R.: Ocean acidification, present conditions and future changes in a high- $\mathrm{CO}_{2}$ world, Oceanography, 22, 36-47, doi:10.5670/oceanog.2009.95, 2009.

Ferek, R. J., Hobbs, P. V., Radke, L. F., Herring, J. A., Sturges, W. T., and Cota, F. C.: Dimethyl sulphide in the arctic atmosphere, J. Geophys. Res., 100, 26093-26104, doi:10.1029/95JD02374, 1995.

Ford, J. D., McDowell, G., and Pearce, T.: The adaptation challenge in the Arctic, Nat. Clim. Change, 5, 1046-1053, doi:10.1038/NCLIMATE2723, 2015.

Frey, K. E., Perovich, D. K., and Light, B.: The spatial distribution of solar radiation under a melting Arctic sea ice cover, Geophys. Res. Lett., 38, L22501, doi:10.1029/2011GL049421, 2011.

Galí, M., Saló, V., Almeda, R., Calbet, A., and Simó, R.: Stimulation of gross dimethylsulfide (DMS) production by solar radiation, Geophys. Res. Lett., 38, L15612, doi:10.1029/2011GL048051, 2011.

Galindo, V., Levasseur, M., Mundy, C. J., Gosselin, M., Scaratt, M., Papakyriakou, T., Stefels, J., Gale, M. A., Tremblay, J.-E., and Lizotte M.: Contrasted sensitivity of DMSP production to high light exposure in two Arctic under-ice blooms, J. Exp. Mar. Biol. Ecol., 475, 38-48, doi:10.1016/j.jembe.2015.11.009, 2016.

Gao, K. and Campbell, D. A.: Photophysiological responses of marine diatoms to elevated $\mathrm{CO}_{2}$ and decreased $\mathrm{pH}$ : a review, Funct. Plant Biol., 41, 449-459, doi:10.1071/FP13247, 2014.

Gilstad, M. and Sakshaug, E.: Growth rates of ten diatom species from the Barents Sea at different irradiances and day lengths, Mar. Ecol.-Prog. Ser., 64, 169-173, 1990.

Hama, T., Inoue, T., Suzuki, R., Kashiwazaki, H., Wada, S., Sasano, D., Kosugi, N., and Ishii, M.: Response of a phytoplankton community to nutrient addition under different $\mathrm{CO}_{2}$ and $\mathrm{pH}$ conditions, J. Oceanogr., 72, 207-223, doi:10.1007/s10872-015-03224, 2016.

Hansen, H. P. and Koroleff, F.: Determination of nutrients, in: Methods of seawater analysis, edited by: Grasshoff, K., Kremling, K., and Ehrhardt, M., Wiley-VCH, Weinheim, 159-228, doi:10.1002/9783527613984, 2007.

Havenhand, J., Dupont, S., and Quinn, G. P.: Designing ocean acidification experiments to maximise inference, in: Guide to Best Practices in Ocean Acidification Research and Data Reporting, edited by: Riebesell, U., Fabry, V. J., and Gattuso, J.-P., Publications Office of the European Union, Luxembourg, 67-80, 2010.

Heimdal, B. R.: Arctic Ocean Phytoplankton, in: The Arctic Seas, edited by: Herman Y., Climatology, Oceanography, Geology, and Biology, Van Nostrand Reinhold Company, New York, USA, 193-222, 1989.

Herndl, G. J., Müller-Niklas, G., and Frick, J.: Major role of ultraviolet-B in controlling bacterioplankton growth in the surface layer of the ocean, Nature, 361, 717-719, doi:10.1038/361717a0, 1993.

Hervé, V., Derr, J., Douady, S., Quinet, M., Moisan, L., and Lopez, P. J.: Multiparametric analyses reveal the $\mathrm{pH}$-dependence of silicon biomineralization in diatoms, PLoS ONE, 7, e46722, doi:10.1371/journal.pone.0046722, 2012.

Holm-Hansen, O., Lorenzen, C. J., Holmes, R. W., and Strickland, J. D. H.: Fluorometric determination of chlorophyll, Journal du Conseil International pour l'Exploration de la Mer, 30, 3-15, doi:10.1093/icesjms/30.1.3, 1965.

Hopkins, F. E. and Archer, S. D.: Consistent increase in dimethyl sulfide (DMS) in response to high $\mathrm{CO}_{2}$ in five shipboard bioassays from contrasting NW European waters, Biogeosciences, 11, 4925-4940, doi:10.5194/bg-11-4925-2014, 2014.

Hopkins, F. E., Turner, S. M., Nightingale P. D., Steinke, M., Bakker, D., and Liss P. S.: Ocean acidification and marine trace gas emissions, P. Natl. Acad. Sci. USA, 107, 760-765, doi:10.1073/pnas.0907163107, 2010.

Johnson, K. M., Wills, K. D., Butler, D. B., Johnson, W. K., and Wong, C. S.: Coulometric total carbon dioxide analysis for marine studies: maximizing the performance of an automated gas extraction system and coloumetric detector, Mar. Chem., 44, 167-187, doi:10.1016/0304-4203(93)90201-X, 1993.

Jones, G. B., Curran, M. A. J., Swan, H. B., Greene, R. M., Griffiths, F. B., and Clementson, L. A.: Influence of different water masses and biological activity on dimethylsulphide and dimethylsulphoniopropionate in the subantarctic zone of the Southern Ocean during ACE 1, J. Geophys. Res., 103, 1669116701, doi:10.1029/98JD01200, 1998.

Keller, M. D., Bellows, W. K., and Guillard, R. R. L.: Dimethyl sulfide production in marine phytoplankton, in: ACS symposium series, edited by: Saltzman, E., and Cooper, W. J.: Biogenic sulfur in the environment, American Chemical Society, Washington DC, USA, 167-182, 1989.

Keller, M. D., Kiene, R. P., Matrai, P. A., and Bellows, W. K.: Production of glycine betaine and dimethylsulfoniopropionate in marine phytoplankton. II. N-limited chemostat cultures, Mar. Biol., 135, 249-257, doi:10.1007/s002270050622, 1999.

Kettle, A. J. and Andreae, M. O.: Flux of dimethylsulfide from the oceans: A comparison of updated data sets and flux models, J. Geophys. Res., 105, 26793-26808, doi:10.1029/2000JD900252, 2000.

Kiene, R. P. and Slezak, D.: Low dissolved DMSP concentrations in seawater revealed by small-volume gravity filtration and dialysis sampling, Limnol. Oceanogr.-Meth., 4, 80-85, doi:10.4319/lom.2006.4.80, 2006.

Kiene, R. P., Linn, L. J., and Bruton, J. A.: The fate of dissolved dimethylsulfoniopropionate (DMSP) in seawater: tracer studies using S-35-DMSP, Geochim. Cosmochim. Ac., 64, 2797-2810, doi:10.1016/s0016-7037(00)00399-9, 2000.

Kim, J.-M., Lee, K., Yang, E. J., Shin, K., Noh, J. H., Park, K.T., Hyun, B., Jeong, H.-J., Kim, J.-H., Kim, K. Y., Kim, M., Kim, H.-C., Jang, P.-G., and Jang, M.-C.: Enhanced production of oceanic dimethylsulfide resulting from $\mathrm{CO}_{2}$-induced grazing activity in a high $\mathrm{CO}_{2}$ world, Environ. Sci. Tech., 44, 8140-8143, doi:10.1021/es102028k, 2010.

Kirst, G. O.: Osmotic adjustment in phytoplankton and macroalgae: the use of dimethylsulfoniopropionate (DMSP), in: Biological and Environ. Chem. of DMSP and related compounds, edited by: Kiene, R. P., Visscher, P., Keller, M., and Kirst, G. O., Plenum, New York, USA, 121-129, 1996.

Kirst, G. O., Thiel, C., Wolff, H., Nothnagel, J., Wanzek, M., and Ulmke, R.: Dimethylsulfoniopropionate (DMSP) in ice- 
algae and its possible biological role, Mar. Chem., 35, 381-388, doi:10.1016/S0304-4203(09)90030-5, 1991.

Kolber, Z., Prášil, O., and Falkowski, P. G.: Measurements of variable chlorophyll fluorescence using fast repetition rate techniques: defining methodology and experimental protocols, Biochim. Biophys. Acta, 1367, 88-106, doi:10.1016/S00052728(98)00135-2, 1998.

Li, W. K. W., McLaughlin, F. A., Lovejoy, C., and Carmack, E. C.: Smallest algae thrive as the Arctic Ocean freshens, Science, 326, p. 539, doi:10.1126/science.1179798, 2009.

Lizotte, M., Levasseur, M., Michaud, S., Scarratt, M. G., Merzouk, A., Gosselin, M., Pommier, J., Rivkin, R. B., and Kiene, R. P.: Macroscale patterns of the biological cycling of dimethylsulfonopropionate (DMSP) and dimethylsulfide (DMS) in the Northwest Atlantic, Biogeochemistry, 110, 183-200, doi:10.1007/s10533-011-9698-4, 2012.

Lohbeck, K. T., Riebesell, U., and Reusch, T. B. H.: Adaptive evolution of a key phytoplankton species to ocean acidification, Nat. Geosci., 5, 346-351, doi:10.1038/ngeo1441, 2012.

Lohbeck, K. T., Riebesell, U., and Reusch, T. B. H.: Gene expression changes in the coccolithophore Emiliana Huxleyi after 500 generations of selection to ocean acidification, P. R. Soc. B., 281, 20140003, doi:10.1098/rspb.2014.0003, 2014.

Lovejoy, C., Vincent, W. F., Bonilla, S., Roy, S., Martineau, M.-J., Terrado, R., Potvin, M., Massana, R., and Pedrós-Alió, C.: Distribution, phylogeny, and growth of cold-adapted picoprasinophytes in arctic seas, J. Phycol., 43, 78-89, doi:10.1111/j.15298817.2006.00310.x, 2007.

Lueker, T. J., Dickson, A. G., and Keeling, C. D.: Ocean $p \mathrm{CO}_{2}$ calculated from dissolved inorganic carbon, alkalinity, and equations for $\mathrm{K} 1$ and $\mathrm{K} 2$ : validation based on laboratory measurements of $\mathrm{CO}_{2}$ in gas and seawater at equilibrium, Mar. Chem., 70, 105-119, doi:10.1016/s0304-4203(00)00022-0, 2000.

Lund, J. W. G., Kipling, C., and Le Cren, E. D.: The inverted microscope method of estimating algal number and the statistical basis of estimations by counting, Hydrobiologia, 11, 143-170, doi:10.1007/BF00007865, 1958.

Maas, E. W., Law, C. S., Hall, J. A., Pickmere, S., Currie, K. I., Chang, F. H., Voyles, K. M., and Caird, D.: Effect of ocean acidification on bacterial abundance, activity and diversity in the Ross Sea, Antarctica, Aquat. Microb. Ecol., 70, 1-15, doi:10.3354/ame01663, 2013.

Macdonald, R. W., Kuzyk, Z. A., and Johannessen, S. C.: It is not just about the ice: a geochemical perspective on the changing Arctic Ocean, Journal of Environmental Studies and Sciences, 5, 288-301, doi:10.1007/s13412-015-0302-4, 2015.

Mackey, K. R. M., Morris, J. J., Morel, F. M. M., and Kranz, S. A.: Response of photosynthesis to ocean acidification, Oceanography, 28, 74-91, doi:10.5670/oceanog.2015.33, 2015.

Marie, D., Brussaard, C. P. D., Thyrhaug R., Bratbak, G., and Vaulot, D.: Enumeration of marine viruses in culture and natural samples by flow cytometry, Appl. Environ. Microb., 65, 45-52, 1999.

Marie, D., Simon, N., and Vaulot, D.: Phytoplankton cell counting by flow cytometry, in: Algal Culturing Techniques, edited by: Andersen, R. A., Elsevier Academic Press, Burlington, MA, USA, 253-268, 2005.

Martin, J., Tremblay, J.-É., Gagnon, J., Tremblay, G., Lapoussière, A., Jose, C., Poulin, M., Gosselin, M., Gratton, Y., and Michel,
C.: Prevalence, structure and properties of subsurface chlorophyll maxima in Canadian Arctic waters, Mar. Ecol.-Prog. Ser., 412, 69-84, doi:10.3354/meps08666, 2010.

Martin, J., Dumont, D., and Tremblay, J.-É.: Contribution of subsurface chlorophyll maxima to primary production in the coastal Beaufort Sea (Canadian Arctic): A model assessment, J. Geophys. Res.-Oceans, 118, 5873-5886, doi:10.1002/2013JC008843, 2013.

Matrai, P. A. and Vernet, M.: Dynamics of the vernal bloom in the marginal ice zone of the Barents Sea: Dimethyl sulfide and dimethylsulfoniopropionate budgets, J. Geophys. Res., 102, 22965-22979, doi:10.1029/96JC03870, 1997.

Maxwell, K. and Johnson, G. N.: Chlorophyll fluorescence - a practical guide, J. Exp. Bot., 51, 659-668, doi:10.1093/jexbot/51.345.659, 2000.

Mejía, L. M., Isensee. K., Méndez-Vicente, A., Pisonero, J., Shimizu, N., González, C., Monteleone, B., and Stoll, H.: B content and $\mathrm{Si} / \mathrm{C}$ ratios from cultured diatoms (Thalassiosira pseudonana and Thalassiosira weissflogii): relationship to seawater $\mathrm{pH}$ and diatom carbon acquisition, Geochim. Cosmochim. Ac., 123, 322-337, doi:10.1016/j.gca.2013.06.011, 2013.

Milligan, A. J., Varela, D. E., Brzezinski, M. A., and Morel, F. M. M.: Dynamics of silicon metabolism and silicon isotopic discrimination in a marine diatom as a function of $p \mathrm{CO}_{2}$, Limnol. Oceanogr., 49, 322-329, doi:10.4319/lo.2004.49.2.0322, 2004.

Mungall, E. L., Croft, B., Lizotte, M., Thomas, J. L., Murphy, J. G., Levasseur, M., Martin, R. V., Wentzell, J. J. B., Liggio, J., and Abbatt, J. P. D.: Dimethyl sulfide in the summertime Arctic atmosphere: measurements and source sensitivity simulations, Atmos. Chem. Phys., 16, 6665-6680, doi:10.5194/acp-16-66652016, 2016.

Newbold, L. K., Olivier, A. E., Booth, T., Tiwari, B., DeSantis, T., Maguire, M., Andersen, G., van der Gast, C. J., and Whiteley, A. S.: The response of marine picoplankton to ocean acidification, Environ. Microbiol., 14, 2293-2307, doi:10.1111/j.14622920.2012.02762.x, 2012.

Palmer, M. A., Saenz, B. T., and Arrigo, K. R.: Impacts of sea ice retreat, thinning, and melt-pond proliferation on the summer phytoplankton bloom in the Chukchi Sea, Arctic Ocean, Deep-Sea Res. Pt. II, 105, 85-104, doi:10.1016/j.dsr2.2014.03.016, 2014.

Park, K.-T., Lee, K., Shin, K., Yang, E. J., Hyun B., Kim, J.-M., Noh, J. H., Kim, M., Kong, B., Choi, D. H., Choi, S.-J., Jang, P.-G., and Jeong, H. J.: Direct linkage between Dimethyl Sulfide Production and Microzooplankton Grazing, Resulting from Prey Composition Change under High Partial Pressure of Carbon Dioxide Conditions, Environ. Sci. Tech., 48, 4750-4756, doi:10.1021/es403351h, 2014.

Parsons, T. R., Maita, Y., and Lalli, C. M.: A Manual of Chemical and Biological Methods for Seawater Analysis, Pergamon, New York, USA, 1984.

Paul, C., Sommer, U., Garzke, J., Moustaka-Gouni, M., Paul, A., and Matthiessen, B.: Effects of increased $\mathrm{CO}_{2}$ concentration on nutrient limited coastal summer plankton depend on temperature, Limnol. Oceanogr., 61, 853-868, doi:10.1002/lno.10256, 2016.

Paulino, A. I., Egge, J. K., and Larsen, A.: Effects of increased atmospheric $\mathrm{CO}_{2}$ on small and intermediate sized osmotrophs during a nutrient induced phytoplankton bloom, Biogeosciences, 5, 739-748, doi:10.5194/bg-5-739-2008, 2008. 
Perovich, D. K., Roesler, C. S., and Pegau, W. S.: Variability in Arctic sea ice optical properties, J. Geophys. Res., 103, 11931208, doi:10.1029/97JC01614, 1998.

Pierrot, D. E., Lewis, E., and Wallace, D. W. R.: MS Excel program developed for $\mathrm{CO}_{2}$ system calculations, Carbon Dioxide Information Analysis Center, ONRL/CDIAC-105a, Oak Ridge National Laboratory, US Department of Energy, Oak Ridge, Tennessee, USA, 2006.

Piontek, J., Borchard, C., Sperling, M., Schulz, K. G., Riebesell, U., and Engel, A.: Response of bacterioplankton activity in an Arctic fjord system to elevated $p \mathrm{CO}_{2}$ : results from a mesocosm perturbation study, Biogeosciences, 10, 297-314, doi:10.5194/bg-10297-2013, 2013.

Poulin, M., Daugbjerg, N., Gradinger, R., Ilyash, L., Ratkova, T., and von Quillfeldt, C.: The pan-Arctic biodiversity of marine pelagic and sea-ice unicellular eukaryotes: a first-attempt assessment, Marine Biodiversity, 41, 13-28, doi:10.1007/s12526-0100058-8, 2011.

Quinn, P. K., Miller, T. L., Bates, T. S., Ogren, J. A., Andrews, E., and Shaw, G. E.: A 3-year record of simultaneously measured aerosol chemical and optical properties at Barrow, Alaska, J. Geophys. Res., 170, 4130, doi:10.1029/2001JD001248, 2002.

Raven, J. R., Caldeira, K., Elderfield, H., Hoegh-Guldberg, O., Liss, P. S., Riebesell, U., Shepherd, J., Turley, C., and Watson, A.: Ocean acidification due to increasing atmospheric carbon dioxide, The Royal Society Policy document $12 / 05$, The Royal Society, London, UK, 2005.

Richier, S., Achterberg, E. P., Dumousseaud, C., Poulton, A. J., Suggett, D. J., Tyrrell, T., Zubkov, M. V., and Moore, C. M.: Phytoplankton responses and associated carbon cycling during shipboard carbonate chemistry manipulation experiments conducted around Northwest European shelf seas, Biogeosciences, 11, 4733-4752, doi:10.5194/bg-11-4733-2014, 2014.

Riebesell, U., Fabry, V. J., Hansson, L., and Gattuso, J.-P. (Eds.): Guide to best practices for ocean acidification research and data reporting, European commission, Brussels, Belgium, 2010.

Riebesell, U., Gattuso, J.-P., Thingstad, T. F., and Middelburg, J. J.: Preface "Arctic ocean acidification: pelagic ecosystem and biogeochemical responses during a mesocosm study", Biogeosciences, 10, 5619-5626, doi:10.5194/bg-10-5619-2013, 2013.

Riley, G. A.: Phytoplankton of the North Central Sargasso Sea 1950-52, Limnol. Oceanogr., 2, 252-270, doi:10.1002/lno.1957.2.3.0252, 1957.

Rost, B., Zondervan, D., and Wolf-Gladrow, D.: Sensitivity of phytoplankton to future changes in ocean carbonate chemistry: Current knowledge, contradictions and research directions, Mar. Ecol.-Prog. Ser., 373, 227-237, doi:10.3354/meps07776, 2008.

Roux, R., Gosselin, M., Desrosiers, G., and Nozais, C.: Effects of reduced UV radiation on a microbenthic community during a microcosm experiment, Mar. Ecol.-Prog. Ser., 229, 29-43, doi:10.3354/meps225029, 2002.

Scarratt, M. G., Levasseur, M., Schultes, S., Michaud, S., Cantin, G., Vézina, A., Gosselin, M., and de Mora, S. J.: Production and consumption of dimethylsulfide (DMS) in North Atlantic waters, Mar. Ecol.-Prog. Ser., 204, 13-26, doi:10.3354/meps204013, 2000.

Schuback, N., Schallenberg, C., Duckham, C., Maldonado, M. T., and Tortell, P. D.: Interacting effects of light and iron availability on the coupling of photosynthetic electron transport and $\mathrm{CO}_{2}$ as- similation in marine phytoplankton, PLoS ONE, 10, e0133235, doi:10.1371/journal.pone.0133235, 2015.

Schuback, N., Flecken, M., Maldonado, M. T., and Tortell, P. D.: Diurnal variation in the coupling of photosynthetic electron transport and carbon fixation in iron-limited phytoplankton in the NE subarctic Pacific, Biogeosciences, 13, 1019-1035, doi:10.5194/bg-13-1019-2016, 2016.

Schulz, K. G., Bellerby, R. G. J., Brussaard, C. P. D., Büdenbender, J., Czerny, J., Engel, A., Fischer, M., Koch-Klavsen, S., Krug, S. A., Lischka, S., Ludwig, A., Meyerhöfer, M., Nondal, G., Silyakova, A., Stuhr, A., and Riebesell, U.: Temporal biomass dynamics of an Arctic plankton bloom in response to increasing levels of atmospheric carbon dioxide, Biogeosciences, 10, 161180, doi:10.5194/bg-10-161-2013, 2013.

Slezak, D., Kiene, R. P., Toole, D. A., Simó, R., and Kieber, D.: Effects of solar radiation on the fate of dissolved DMSP and conversion to DMS in seawater, Aquat. Sci., 69, 377-393, doi:10.1007/s00027-007-0896-z, 2007.

Stefels, J.: Physiological aspects of the production and conversion of DMSP in marine algae and higher plants, J. Sea Res., 43, 183197, doi:10.1016/S1385-1101(00)00030-7, 2000.

Stefels, J., Steinke, M., Turner, S., Malin, G., and Belviso, S.: Environmental constraints on the production and removal of the climatically active gas dimethylsulphide (DMS) and implications for ecosystem modelling, Biogeochemistry, 83, 245-275, doi:10.1007/978-1-4020-6214-8_18, 2007.

Steinacher, M., Joos, F., Frölicher, T. L., Plattner, G.-K., and Doney, S. C.: Imminent ocean acidification in the Arctic projected with the NCAR global coupled carbon cycle-climate model, Biogeosciences, 6, 515-533, doi:10.5194/bg-6-515-2009, 2009.

Sunda, W., Kieber, D. J., Kiene, R. P., and Huntsman, S.: An antioxidant function for DMSP and DMS in marine algae, Nature, 418, 317-320, doi:10.1038/nature00851, 2002.

Sunda, W., Hardison, R., Kiene, R. P., Bucciarelli, E., and Harada, H.: The effect of nitrogen limitation on cellular DMSP and DMS release in marine phytoplankton: climate feedback implication, Aquat. Sci., 69, 341-351, doi:10.1007/s00027-007-0887$0,2007$.

Thoisen, C., Riisgaard, K., Lundholm, N., Nielsen, T. G., and Hansen, P. J.: Effect of acidification on an Arctic phytoplankton community from Disko Bay, West Greenland, Mar. Ecol.-Prog. Ser., 520, 21-34, doi:10.3354/meps11123, 2015.

Toole, D. A. and Siegel, A. D.: Light-driven cycling of dimethylsulfide (DMS) in the Sargasso Sea: closing the loop, Geophys. Res. Lett., 31, L09308, doi:10.1029/2004GL019581, 2004.

Townsend, D. W. and Keller, M. D.: Dimethylsulfide (DMS) and dimethylsulfoniopropionate (DMSP) in relation to phytoplankton in the Gulf of Maine, Mar. Ecol.-Prog. Ser., 137, 229-241, doi:10.3354/meps137229, 1996.

Tremblay, G., Belzile, C., Gosselin, M., Poulin, M., Roy, S., and Tremblay, J.-É.: Late summer phytoplankton distribution along $3500 \mathrm{~km}$ transect in Canadian Arctic waters: strong numerical dominance by picoeukaryotes, Aquat. Microb. Ecol., 54, 55-70, doi:10.3354/ame01257, 2009.

Tremblay, J.-E., Gratton, Y., Carmack, E. C., Payne, C. D., and Price, N. M.: Impact of the large-scale Arctic circulation and the North Water Polynia on nutrient inventories in Baffin Bay, J. Geophys. Res., 107, 3112, doi:10.1029/2000JC000595, 2002. 
Tremblay, J.-E., Michel, C., Hobson, K. A., Gosselin, M., and Price, N. P.: Bloom dynamics in early opening waters of the Arctic Ocean, Limnol. Oceanogr., 51, 900-912, doi:10.4319/lo.2006.51.2.0900, 2006.

Tremblay, J.-E., Robert D., Varela, D. E., Lovejoy, C., Darnis, G., Nelson, R. J., and Sastri, A. R.: Current State and trends in Canadian Arctic marine ecosystems : I. Primary production, Climatic Change, 115, 161-178, doi:10.1007/s10584-012-0496-3, 2012.

Trodahl, H. J. and Buckley, R. G.: Enhanced ultraviolet transmission of Antarctic sea ice during the austral spring, Geophys. Res. Lett., 17, 2177-2179, doi:10.1029/GL017i012p02177, 1990.

Vallina, S. M. and Simó, R.: Strong relationship between DMS and the solar radiation dose over the global surface ocean, Science, 315, 506-508, doi:10.1126/science.1133680, 2007.

Van Bergeijk, S., Van Der Zee, C., and Stal, L. J.: Uptake and excretion of dimethylsulphoniopropionate is driven by salinity changes in the marine benthic diatom Cylindrotheca closterium, Eur. J. Phycol., 38, 341-349, doi:10.1080/09670260310001612600, 2003.

Vance, T. R., Davidson, A. T., Thomson, P. G., Levasseur, M., Lizotte, M., Curran, M. A. J., and Jones, G. B.: Rapide DMSP production by an Antarctic phytoplankton community exposed to natural surface irradiances in late spring, Aquat. Microb. Ecol., 71, 117-129, doi:10.3354/ame01670, 2013.

Vogt, M., Steinke, M., Turner, S., Paulino, A., Meyerhöfer, M., Riebesell, U., LeQuéré, C., and Liss, P.: Dynamics of dimethylsulphoniopropionate and dimethylsulphide under different $\mathrm{CO}_{2}$ concentrations during a mesocosm experiment, Biogeosciences, 5, 407-419, doi:10.5194/bg-5-407-2008, 2008.
Von Quillfeldt, C. H.: Common diatom species in arctic spring blooms: their distribution and abundance, Bot. Mar., 43, 499516, doi:10.1515/BOT.2000.050, 2000.

Webb, A. L., Malin, G., Hopkins, F. E., Ho, K. L., Riebesell, U., Schulz, K. G., Larsen, A., and Liss, P. S.: Ocean acidification has different effects on the production of dimethylsulfide and dimethylsulfoniopropionate measured in cultures of Emiliana huxleyi and a mesocosm study: a comparison of laboratory monocultures and community interactions, Environ. Chem., 13, 314-329, doi:10.1071/EN14268, 2015.

Webb, A. L., Leedham-Elvidge, E., Hughes, C., Hopkins, F. E., Malin, G., Bach, L. T., Schulz, K., Crawfurd, K., Brussaard, C. P. D. Stuhr, A., Riebesell, U., and Liss, P. S.: Effect of ocean acidification and elevated $f \mathrm{CO}_{2}$ on trace gas production by a Baltic Sea summer phytoplankton community, Biogeosciences, 13, 45954613, doi:10.5194/bg-13-4595-2016, 2016.

Wolfe, G. V., Levasseur, M., Cantin G., and Michaud, S.: Microbial consumption and production of dimethyl sulphide (DMS) in the Labrador Sea, Aquat. Microb. Ecol., 18, 197-205, doi:10.3354/ame018197, 1999.

Wu, Y., Campbell, D. A., Irwin A. J., Suggett, D. J., and Finkel, Z. V.: Ocean acidification enhances the growth rate of larger diatoms, Limnol. Oceanogr., 59, 1027-1034, doi:10.4319/lo.2014.59.3.1027, 2014. 